\title{
A ELITE PARLAMENTAR BRASILEIRA (1989-2004)
}

\author{
Débora Messenberg*
}

Resumo: O presente artigo analisa o perfil dos parlamentares que fizeram parte da elite parlamentar brasileira ao longo dos anos de 1989 a 2004, procurando não só identificar os atores e suas práticas políticas, mas compreender de que maneira diferentes matizes socioculturais interferem no fazer e pensar a política no Brasil.

Palavras-chave: elite parlamentar, dimensão sociocultural, Congresso Nacional.

No ano de 2002 foi lançado pela editora Brasiliense livro de minha autoria intitulado $A$ elite parlamentar do pós-Constituinte: atores e práticas. Trata-se de uma obra que procurou desvendar quem eram, como atuaram politicamente e o que pensavam os atores sociais que fizeram parte da elite parlamentar, após a promulgação da Constituição da República Federativa do Brasil, em outubro de 1988.

De modo específico, foi enfocado o período de 1989 a 1994, momento extremamente rico e crucial da história política brasileira, marcado pela revitalização do Parlamento após 21 anos de ditadura militar e que abrange três governos diferentes (José Sarney, Fernando Collor de Mello e Itamar Franco) e duas legislaturas (a $48^{\mathrm{a}}$ e a $49^{\mathrm{a}}$ ).

\footnotetext{
Professora do Departamento de Sociologia da Universidade de Brasília (UnB). E-mail: deboramess@gmail.com

Texto apresentado no $30^{\circ}$ Encontro Anual da ANPOCS, no Grupo de Trabalho 07 - Estudos Legislativos.
}

Artigo recebido em 16 mar. 2007 e aprovado em 2 jul. 2007. 
Foi realizada ampla pesquisa bibliográfica e empírica, a qual resultou em material de análise extremamente rico, considerando o ineditismo da temática, a relevância das entrevistas efetuadas e a envergadura dos políticos entrevistados. ${ }^{1}$ Além disso, crê-se ter contemplado, ao final do trabalho, as questões propostas quanto à definição dos atributos que recobriram o perfil e as práticas dos membros da elite parlamentar pós-Constituinte, assim como os mecanismos institucionais que possibilitaram a existência e a reprodução desse seleto grupo.

No intuito de atualizar e renovar as informações contidas no livro supracitado e aprofundar temáticas ainda não suficientemente exploradas quanto à dimensão sociocultural do fazer e pensar a política no Brasil, propusemo-nos à realização de uma nova pesquisa, cujos resultados serão aqui, em parte, apresentados, ${ }^{2}$ e que consiste na investigação do perfil dos parlamentares que fizeram parte da elite parlamentar brasileira ao longo dos anos de 1995 a 2004. O período recobre três legislaturas $\left(50^{\mathrm{a}}, 51^{\mathrm{a}}\right.$ e parte da $\left.52^{\mathrm{a}}\right)$ e três mandatos presidenciais (os dois governos de Fernando Henrique Cardoso e os dois primeiros anos do governo de Luís Inácio Lula da Silva).

Procurou-se não só identificar os atores e suas práticas políticas, mas compreender de que maneira diferentes matizes socioculturais interferem no processo de construção e consolidação de suas carreiras e identidades enquanto políticos. Para tanto, foi empreendida uma investigação acerca do perfil sociocultural, econômico e ideológico dos membros da elite parlamentar, e, também, de suas trajetórias políticas.

Este estudo pretende, assim, traçar uma morfologia da elite parlamentar do Congresso Nacional Brasileiro durante os anos de 1989 a 2004, no sentido de caracterizá-la social, econômica e profissionalmente e quanto ao desenvolvimento de suas carreiras políticas em termos comparativos com os demais congressistas em 
relação às características internas desse grupo, a partir de um recorte sociocultural relativo à região eleitoral dos parlamentares.

\section{Morfologia da elite parlamentar brasileira (1989-2004)}

É amplamente reconhecido entre parlamentares, estudiosos da política e mesmo leigos, que, no interior do Poder Legislativo, a capacidade de tomar e impor decisões válidas a todos os membros da instituição concentra-se num círculo restrito de pessoas. Essa característica elitista do Parlamento é aqui entendida não como um fenômeno natural, mas resultado de um processo em que se estabelecem critérios seletivos - também produtos sociais - mediante os quais se opera o recrutamento de determinados parlamentares para a ocupação de "espaços de poder". Tais espaços referem-se tanto às posições estratégicas na estrutura da organização quanto a determinadas práticas que criam e envolvem recursos de poder. Tem-se, assim, configurada, no âmbito do Poder Legislativo, a presença de uma elite parlamentar.

Tomando como referência o Congresso Nacional brasileiro, cabe admitir que a ascendência de um parlamentar à elite encontrase relacionada a certos condicionantes, que podem ser atendidos de forma parcial ou total, aludindo principalmente às seguintes questões: a ocupação de postos-chave do Poder Legislativo; a representação de interesses sociais e/ou institucionais organizados e a posse individual de faculdades "especiais", ${ }^{3}$ reconhecidas entre os membros dessa comunidade como próprias de um líder.

Dessa forma, pode-se definir a elite parlamentar brasileira como um grupo seleto de congressistas, cujos membros se destacam dos demais participantes do Congresso Nacional em função das posições que ocupam, dos interesses que representam e/ou da reputação alcançada. São, enfim, os parlamentares que, dispondo de 
determinados recursos de poder, exercem influência terminante nas principais decisões do Congresso Nacional e do Estado, interferindo de maneira decisiva nos rumos da sociedade.

Para a definição do universo dos parlamentares que integraram em algum momento a elite parlamentar durante os anos considerados, estabeleceram-se quatro critérios fundamentais, são eles: a ocupação de postos estratégicos no Congresso Nacional (presidente e $1^{\circ}$ secretários das Mesas Diretoras, lideranças partidárias e de governo); relator e/ou autor das principais proposições que foram convertidas em lei durante o período ou das principais CPIs; presidente de comissões permanentes e/ou comissões especiais e CPIs; e, parlamentares indicados como membros da elite pela maioria ou totalidade dos congressistas entrevistados em survey realizado com representantes incontestes da elite parlamentar do pós-Constituinte. A partir desse universo, foi calculada a amostra estratificada, utilizando o Método Proporcional de C.P.Paul, sendo os estratos determinados segundo a filiação partidária. Chegou-se, assim, a uma amostra de 47 parlamentares distribuídos de acordo com o total de representantes de cada partido na elite para o período de 1989 a 1995 e de 45 parlamentares para o período de 1995 a 2004 , tendo em vista que as pesquisas se deram em fases distintas.

Para identificar e selecionar os parlamentares que fizeram parte da elite parlamentar do Congresso Nacional ao longo do período considerado, adotou-se, inicialmente, como critério para a determinação dos estratos da amostra, a filiação partidária. Considerando a importância desse aspecto no controle do processo decisório e na organização dos trabalhos legislativos, não houve dúvida de que esse era o melhor recorte a ser efetuado para garantir a representatividade da amostra. Entretanto, durante a análise dos dados primários e secundários, observou-se que, para o esclarecimento das distinções internas à elite, o critério mais rico e elucidativo era o da região eleitoral - entendida não apenas como o lugar de 
representação do parlamentar, mas, principalmente, enquanto locus da construção de sua carreira e do seu ser político.

Neste sentido, o recorte da elite em termos regionais visa exatamente trazer à tona realidades sociais distintas, de onde emergem tipos singulares de parlamentares. Estes, por sua vez, trazem - no seu pensar e no seu fazer política -, marcas de sua identidade cultural/regional, as quais, ao mesmo tempo que os distinguem, não os impedem de compartilhar culturalmente com outros uma série de características que os particularizam enquanto membros da elite do Congresso Nacional Brasileiro.

Cabe ressaltar, ainda, que, apesar de tal recorte possibilitar o alinhamento de informações relacionadas a particularidades regionais dessa elite, deve-se ter em mente que essas particularidades podem, ou não, ser compartilhadas pelos demais congressistas das respectivas regiões. Com essa ressalva pretende-se deixar claro que as marcas da identidade cultural/regional observadas na ação e no pensar desses parlamentares não são sinais "genéticos" a impregnar inexoravelmente a todos os que ali se constroem como políticos. São sim, registros da história político-cultural brasileira e, por conseguinte, produtos do dinamismo e das contradições que distinguem o desenrolar de tal processo nas diferentes regiões do País, terminando por influir diretamente no pensar e fazer política dessas coletividades.

Um outro aspecto relacionado a esse recorte metodológico, diz respeito à construção de três agrupamentos na elite que foram assim classificados: o do Nordeste, o do Sudeste e o do Sul. À indagação sobre a ausência dos agrupamentos de parlamentares da elite do Norte e do Centro-Oeste, poder-se-ia contra-argumentar que tal ausência resulta da baixa participação, ao longo do período em análise, dos representantes dessas regiões no seio da elite parlamentar, inviabilizando a construção dos respectivos agrupamentos. ${ }^{4}$ 
Assim, comparando-se informações acerca do perfil do Congresso Nacional (1989-2004) com os dados obtidos nas pesquisas sobre a elite parlamentar, revelam-se traços importantes de reprodução e rompimento de certas características próprias ao tipo padrão de parlamentar brasileiro.

Isto posto, observa-se nas Tabelas 1A e 1B que, tal como verificado nas Tabelas 1C e 1D (Anexo), há, na elite parlamentar, até a 51 ${ }^{\text {a }}$ Legislatura (1999-2003), ligeira predominância de congressistas naturais do Nordeste $(36,2 \%)$, seguidos de perto pelos parlamentares do Sudeste (34\%). A partir dessa legislatura assiste-se a certa inversão, no sentido de uma leve supremacia dos parlamentares nascidos no Sudeste em relação aos nordestinos natos. Tal inversão corresponde ao crescimento de dois partidos cuja base eleitoral majoritária ainda se mantém no Sudeste, a despeito de suas crescentes expansões para outras regiões do País, quais sejam: o PSDB e o PT. ${ }^{5}$

\section{Tabela 1A - Posição da elite, por naturalidade ${ }^{1}$ Brasil - 1987 a 1995}

\begin{tabular}{|c|c|c|c|c|c|c|c|c|}
\hline \multirow{3}{*}{ Região } & \multicolumn{8}{|c|}{ 1987-1995 } \\
\hline & \multicolumn{2}{|c|}{ Interior } & \multicolumn{2}{|c|}{ Capital } & \multicolumn{2}{|c|}{ Naturalizado } & \multicolumn{2}{|c|}{ Total } \\
\hline & $\begin{array}{c}\mathrm{n}^{\circ} \\
\text { abs. }\end{array}$ & $(\%)$ & $\begin{array}{c}\mathrm{n}^{\mathrm{o}} \\
\mathrm{abs} .\end{array}$ & $(\%)$ & $\begin{array}{c}\mathrm{n}^{\mathrm{o}} \\
\mathrm{abs}\end{array}$ & $(\%)$ & $\mathrm{n}^{\circ}$ abs. & $(\%)$ \\
\hline Norte & 1 & 25,0 & 3 & 75,0 & - & - & 4 & 100,0 \\
\hline Nordeste & 9 & 52,9 & 8 & 47,1 & - & - & 17 & 100,0 \\
\hline Centro-Oeste & - & - & 1 & 100,0 & - & - & 1 & 100,0 \\
\hline Sudeste & 7 & 43,7 & 9 & 56,3 & - & - & 16 & 100,0 \\
\hline Sul & 7 & 87,5 & 1 & 12,5 & - & - & 8 & 100,0 \\
\hline Exterior & - & - & - & - & 1 & 100,0 & 1 & 100,0 \\
\hline Total & 24 & 51,1 & 22 & 46,8 & 1 & 2,1 & 47 & 100,0 \\
\hline
\end{tabular}

Fonte: Câmara dos Deputados (Repertório Biográfico) e Senado Federal (Dados Biográficos). 


\section{Tabela 1B - Composição da elite, por naturalidade Brasil - 1995 a 2004}

\begin{tabular}{lc|c|c|c|c|c|c|c|} 
& \multicolumn{10}{c|}{$\mathbf{1 9 9 5 - 2 0 0 4}$} \\
\cline { 2 - 9 } \multicolumn{1}{c}{ Região } & \multicolumn{2}{c|}{ Interior } & \multicolumn{2}{c|}{ Capital } & \multicolumn{2}{c|}{ Naturalizado } & \multicolumn{2}{c|}{ Total } \\
\cline { 2 - 10 } & $\begin{array}{c}\mathrm{n}^{\mathbf{0}} \\
\text { abs. }\end{array}$ & $\mathbf{( \% )}$ & $\begin{array}{c}\mathrm{n}^{\mathbf{o}} \\
\text { abs. }\end{array}$ & $\mathbf{( \% )}$ & $\begin{array}{c}\mathrm{n}^{\mathbf{o}} \\
\text { abs. }\end{array}$ & $\mathbf{( \% )}$ & $\begin{array}{c}\mathrm{n}^{\mathbf{0}} \\
\text { abs. }\end{array}$ & $\mathbf{( \% )}$ \\
\hline Norte & - & - & 3 & 100,0 & - & - & 3 & 100,0 \\
Nordeste & 11 & 61,1 & 7 & 38,9 & - & - & 18 & 100,0 \\
Sudeste & 10 & 52,6 & 9 & 47,4 & - & - & 19 & 100,0 \\
Sul & - & - & 4 & 100,0 & - & - & 4 & 100,0 \\
Exterior & - & - & - & - & 1 & 100,0 & 1 & 100,0 \\
Total & $\mathbf{2 1}$ & $\mathbf{4 6 , 7}$ & $\mathbf{2 3}$ & $\mathbf{5 1 , 1}$ & $\mathbf{1}$ & $\mathbf{2 , 2}$ & $\mathbf{4 5}$ & $\mathbf{1 0 0 , 0}$ \\
\hline
\end{tabular}

Fonte: Câmara dos Deputados (Repertório Biográfico) e Senado Federal (Dados Biográfi$\cos )$.

Entre os parlamentares da elite nascidos no Sul, observa-se uma queda significativa $(47,7 \%)$ dos naturais dessa região, durante as $50^{\mathrm{a}}, 51^{\mathrm{a}}$ e $52^{\mathrm{a}}$ legislaturas. Se, entre 1989 a 1995 , eles chegaram a representar $17 \%$ dos parlamentares da elite, nas legislaturas seguintes não ultrapassaram 9\%. Essa diminuição encontra-se diretamente relacionada à própria redução $(47,9 \%)$ dos representantes - naturais ou não - dessa região na elite. A queda na participação dos representantes da Região Sul na elite (Tabelas 2A e 2B) remonta à progressiva diminuição da bancada do PMDB no Congresso Nacional e ao enfraquecimento político desse partido frente a coligação PSDB e PFL. ${ }^{6}$ Efetivamente, dos parlamentares da elite nascidos no Sul, durante os anos de 1989 a 1994, 87,5\% eram representantes do PMDB. Nas últimas legislaturas, dos parlamentares da elite sulistas natos, apenas $20 \%$ foram representantes desse partido.

Nota-se, ainda que a presença de parlamentares oriundos das capitais dos Estados foi muito superior àquela verificada no Parlamento como um todo. Enquanto no Congresso, durante as Legislaturas em foco, 34\% dos parlamentares, em média, eram naturais das capitais (Tabelas 1C e 1D, Anexo), na elite, esta proporção era de $46.8 \%$, durante as $48^{\mathrm{a}}$ e $49^{\mathrm{a}}$ legislaturas, e $51,1 \%$ 
nas seguintes. Internamente às regiões, observam-se variações durante os períodos analisados. Enquanto que nas duas primeiras legislaturas investigadas constatam-se, entre os membros da elite, percentuais mais elevados de parlamentares naturais das capitais dos Estados do Sudeste e do Norte, nas legislaturas seguintes, somente os procedentes do Norte e do Sul são de origem metropolitana. Dentre os nativos do Nordeste, a predominância dos nascidos no interior dos Estados manteve-se ao longo de todo período. Há que se destacar, porém, que, em termos comparativos ao Congresso Nacional, os membros da elite superam, em todas as regiões, aqueles naturais das capitais dos Estados. De fato, 56,3\% dos parlamentares do Sudeste e $47,1 \%$ do Nordeste, entre 1989 a 1995, e 47,4\% e 38,9\%, entre 1995 e 2004, os pertencentes à elite, eram oriundos das capitais, contra, respectivamente, em média, nas duas legislaturas, $34,1 \%$ e $36,5 \%$ no Congresso.

A participação mais elevada de parlamentares oriundos das capitais dos Estados, na elite, comparativamente ao Congresso Nacional, adquire novos significados, quando se cruzam informações relativas à naturalidade de seus integrantes, com dados referentes à região eleitoral.

\section{Tabela 2A - Composição da elite, por naturalidade e região eleitoral - Brasil - 1987-1995}

\begin{tabular}{|c|c|c|c|c|c|c|c|c|c|c|}
\hline \multirow{3}{*}{$\begin{array}{l}\text { Naturali- } \\
\text { dade }\end{array}$} & \multicolumn{10}{|c|}{ Região eleitoral } \\
\hline & \multicolumn{2}{|c|}{ Norte } & \multicolumn{2}{|c|}{ Nordeste } & \multicolumn{2}{|c|}{ Sudeste } & \multicolumn{2}{|c|}{ Sul } & \multicolumn{2}{|c|}{ Total } \\
\hline & $\begin{array}{c}\mathrm{n}^{\mathrm{o}} \\
\mathrm{abs} .\end{array}$ & $(\%)$ & $\begin{array}{c}\mathrm{n}^{\mathrm{o}} \\
\mathrm{abs} .\end{array}$ & $(\%)$ & $\begin{array}{c}\mathrm{n}^{\mathrm{o}} \\
\mathrm{abs} .\end{array}$ & $(\%)$ & $\begin{array}{c}\mathrm{n}^{\mathbf{o}} \\
\mathrm{abs} .\end{array}$ & $(\%)$ & $\begin{array}{c}\mathbf{n}^{\mathbf{0}} \\
\text { abs. }\end{array}$ & $(\%)$ \\
\hline Norte & 3 & 75,0 & - & - & 1 & 25,0 & - & - & 4 & 100,0 \\
\hline Nordeste & - & - & 12 & 70,6 & 4 & 23,5 & 1 & 5,9 & 17 & 100,0 \\
\hline Centro-Oeste & - & - & - & - & 1 & 100,0 & - & - & 1 & 100,0 \\
\hline Sudeste & - & - & 1 & 6,2 & 14 & 87,5 & 1 & 6,2 & 16 & 100,0 \\
\hline Sul & - & - & - & - & - & - & 8 & 100,0 & 8 & 100,0 \\
\hline Exterior & - & - & 1 & 100,0 & - & - & - & - & 1 & 100,0 \\
\hline
\end{tabular}

Fonte: Câmara dos Deputados (Repertório Biográfico) e Senado Federal (Dados Biográfi$\cos )$. 


\section{Tabela 2B - Composição da elite, por naturalidade e região eleitoral - Brasil - 1995 a 2004}

\begin{tabular}{|c|c|c|c|c|c|c|c|c|c|c|}
\hline \multirow{3}{*}{$\begin{array}{l}\text { Naturali- } \\
\text { dade }\end{array}$} & \multicolumn{10}{|c|}{ Região eleitoral } \\
\hline & \multicolumn{2}{|c|}{ Norte } & \multicolumn{2}{|c|}{ Nordeste } & \multicolumn{2}{|c|}{ Sudeste } & \multicolumn{2}{|c|}{ Sul } & \multicolumn{2}{|c|}{ Total } \\
\hline & $\begin{array}{c}\mathrm{n}^{\circ} \\
\mathrm{abs} .\end{array}$ & $(\%)$ & $\begin{array}{l}\mathrm{n}^{\mathrm{o}} \\
\mathrm{abs} .\end{array}$ & $(\%)$ & $\begin{array}{c}\mathrm{n}^{\circ} \\
\text { abs. }\end{array}$ & $(\%)$ & $\begin{array}{c}\mathrm{n}^{\circ} \\
\mathrm{abs} .\end{array}$ & $(\%)$ & $\begin{array}{c}n^{0} \\
\text { abs. }\end{array}$ & $(\%)$ \\
\hline Norte & 3 & 100,0 & - & - & - & - & - & - & 3 & 100,0 \\
\hline Nordeste & - & - & 17 & 94,4 & 1 & 5,6 & - & - & 18 & 100,0 \\
\hline Sudeste & - & - & - & & 17 & 89,5 & 2 & 10,5 & 19 & 100,0 \\
\hline Sul & - & - & 1 & 25,0 & - & - & 3 & 75,0 & 4 & 100,0 \\
\hline Exterior & - & - & - & - & 1 & 100,0 & - & - & 1 & 100,0 \\
\hline
\end{tabular}

Fonte: Câmara dos Deputados (Repertório Biográfico) e Senado Federal (Dados Biográfi$\cos )$.

Como se verifica nas tabelas $2 \mathrm{~A}$ e $2 \mathrm{~B}$, a preponderância de representantes do Sudeste no interior da elite envolve alguns aspectos importantes.

Em primeiro lugar, não há como negar que a supremacia dos representantes do Sudeste na elite encontra-se diretamente relacionada ao maior desenvolvimento econômico da região, propiciador do acesso - ainda que relativamente restrito -, ao que há de mais moderno no País em termos de educação, tecnologia e serviços. Soma-se a isso, a alta densidade demográfica vigente nos Estados dessa região, engendrando uma grande variedade de segmentos e organizações sociais. Igualmente, a condição do Sudeste como principal pólo atrativo para contingentes populacionais que migram das mais diferentes localidades brasileiras favorece a concentração de múltiplas identidades culturais em seus Estados. Essa ampla diversidade sociocultural e econômica garante aos políticos da referida região uma posição privilegiada na conquista dos espaços públicos de poder no País. Esses são, sem dúvida, alguns aspectos importantes que auxiliam a construção, no Sudeste, de tipos diferenciados de lideranças. 
Em segundo lugar, deve-se observar que, ao contrário do que se verificou nas $48^{\mathrm{a}}$ e $49^{\mathrm{a}}$ legislaturas, onde o percentual de representantes do Sudeste na elite $(42,5 \%)$ foi consideravelmente maior do que aquele apurado entre os naturais dessa região (34\%), nas $50^{\mathrm{a}}, 51^{\mathrm{a}}$ e $52^{\mathrm{a}}$ legislaturas há paridade entre os percentuais dos representantes e dos nativos dessa região (42,2\%). Tal situação também se observa, em menor grau, na região Sul, que, entre 1989 e 1995 , detinha $21,3 \%$ dos membros da elite, e, nas legislaturas seguintes, $11,1 \%$, apesar de, respectivamente, $17 \%$ e $8,9 \%$ do total da elite terem lá nascido.

Quanto aos representantes nordestinos, houve um crescimento significativo desses parlamentares no seio da elite. Entre 1989 e 1995 , correspondiam a $29,8 \%$ da elite, passando a compor, nas legislaturas posteriores, cerca de $40 \%$. Além disso, verifica-se um aumento considerável no percentual de representantes nordestinos que nasceram na própria região. Se, nas duas primeiras legislaturas analisadas, 29,4\% dos nativos do Nordeste não atuavam politicamentenaregião,nasúltimaslegislaturas somente $5,6 \%$ dosnordestinos natos da elite não representavam seu local de origem no parlamento. A maior participação dos representantes nordestinos na elite, a partir da $50^{\mathrm{a}}$ legislatura deve-se, efetivamente, à coligação vitoriosa entre o PFL e o PSDB nas eleições de 1994 e 1998. Considerando que o PFL é um partido eminentemente de base eleitoral no Nordeste, não surpreende o crescimento de seus representantes na elite do Congresso Nacional. Em verdade, nas últimas legislaturas, 77,8\% dos parlamentares do PFL da elite eram nordestinos.

$\mathrm{O}$ aumento na paridade entre parlamentares nascidos $\mathrm{e}$ representantes da mesma região, principalmente, no que se refere aos congressistas do Nordeste, explica-se pela redução de migrantes na elite. Com efeito, se, nas $48^{\mathrm{a}}$ e $49^{\mathrm{a}}$ legislaturas $29,4 \%$ dos naturais do Nordeste da elite migraram para outras regiões, principalmente em direção ao Sudeste do País (23,5\%), nas legislaturas posteriores 
somente 5,6\% procederam dessa forma. Essas informações indicam que as lideranças do Congresso Nacional, cada vez mais são constituídas por políticos cuja vida pública é forjada, prioritariamente, nas suas regiões de origem e isso tem influência decisiva na forma como entendem e praticam a política.

Outro aspecto importante a respeito da representação regional dos participantes da elite parlamentar alude aos Estados da Federação pelos quais se elegeram os congressistas. Contando com $23,9 \%$ dos representantes da elite ao longo de todo período, surge, em primeiro lugar, o Estado de São Paulo, seguido por Rio de Janeiro (13\%), Pernambuco (11,9\%), Bahia (9,8\%), Rio Grande do Sul (7,6\%), Paraná (5,4\%), Minas Gerais e Ceará (4,3\%) Pará, Amazonas e Santa Catarina (3,3\%), Paraíba, Alagoas e Maranhão (2,2\%) e, finalmente, Espírito Santo, Sergipe e Rio Grande do Norte $(1,1 \%)$.

Interessante observar que os membros da elite parlamentar do pós-Constituinte representam, em sua maioria, os Estados (SP, RJ, PE, BA, RS) que, além da sua importância econômica, apresentam, tradicionalmente, lideranças políticas atuantes na vida pública do País. Exceção à regra, registra-se a fraca participação, na elite parlamentar, dos representantes do Estado de Minas Gerais, a qual não corresponde à tradicional relevância política de diversos parlamentares mineiros na história política brasileira. ${ }^{7}$

Outro aspecto caracterizador do perfil da elite parlamentar do pós-Constituinte refere-se ao grau de instrução de seus componentes. Conforme as Tabelas 3A e 3B, a maioria absoluta dos membros da elite $(89,4 \%$ e $88,9 \%)$ dispunha de diploma de nível superior. Em termos comparativos, esse percentual encontra-se ligeiramente acima daquele verificado, em média, no Parlamento ( $83 \%$ - ver Tabela 4C, no Anexo), No que alude à diversidade dos graus de instrução no interior da elite, observa-se que essa era mais acentuada entre os parlamentares do Sudeste, o que não surpreende, posto que 
a região concentra a representação da maior variedade de categorias sociais, recobrindo, por conseguinte, diferentes níveis de exigência quanto à escolarização de seus representantes.

\section{Tabela 3A - Composição da elite, por região eleitoral e grau de instrução - Brasil - 1987 a 1995}

\begin{tabular}{|c|c|c|c|c|c|c|c|c|c|c|}
\hline \multirow{3}{*}{$\begin{array}{c}\text { Região } \\
\text { eleitoral }\end{array}$} & \multicolumn{10}{|c|}{ Grau de instrução } \\
\hline & \multicolumn{2}{|c|}{$\begin{array}{l}\text { Nível médio } \\
\text { completo }\end{array}$} & \multicolumn{2}{|c|}{$\begin{array}{c}\text { Superior } \\
\text { incompleto }\end{array}$} & \multicolumn{2}{|c|}{$\begin{array}{l}\text { Superior } \\
\text { completo }\end{array}$} & \multicolumn{2}{|c|}{$\begin{array}{l}\text { Não reve- } \\
\text { lado }\end{array}$} & \multicolumn{2}{|c|}{ Total } \\
\hline & $\begin{array}{c}n^{0} \\
\text { abs. }\end{array}$ & $(\%)$ & $\begin{array}{c}n^{\circ} \\
\text { abs. }\end{array}$ & $(\%)$ & $\begin{array}{c}n^{0} \\
\text { abs. }\end{array}$ & $(\%)$ & $\begin{array}{c}n^{0} \\
\text { abs. }\end{array}$ & $(\%)$ & $\begin{array}{c}\mathrm{n}^{0} \\
\text { abs. }\end{array}$ & $(\%)$ \\
\hline Norte & - & - & - & - & 3 & 100,0 & - & - & 3 & 100,0 \\
\hline Nordeste & - & - & 1 & 7,1 & 12 & 85,7 & 1 & 7,1 & 14 & 100,0 \\
\hline Sudeste & 1 & 5,0 & 2 & 10,0 & 17 & 85,0 & - & - & 20 & 100,0 \\
\hline Sul & - & - & - & - & 10 & 100,0 & - & - & 10 & 100,0 \\
\hline
\end{tabular}

Fonte: Câmara dos Deputados (Repertório Biográfico) e Senado Federal (Dados Biográfi$\cos )$.

\section{Tabela 3B - Composição da elite, por região eleitoral e grau de instrução - Brasil - 1995 a 2004}

\begin{tabular}{l|c|c|c|c|c|c|c|c}
\hline \multirow{4}{*}{ Região eleitoral } & \multicolumn{7}{c}{ Grau de instrução } \\
\cline { 2 - 9 } & $\begin{array}{c}\text { Nível Médio } \\
\text { Completo }\end{array}$ & \multicolumn{2}{c|}{$\begin{array}{c}\text { Superior In- } \\
\text { completo }\end{array}$} & \multicolumn{2}{c|}{$\begin{array}{c}\text { Superior } \\
\text { Completo }\end{array}$} & \multicolumn{2}{|c}{ TOTAL } \\
\cline { 2 - 10 } & $\begin{array}{c}\mathbf{n}^{\mathbf{0}} \\
\text { abs. }\end{array}$ & $(\%)$ & $\mathbf{n}^{\mathbf{0}}$ abs. & $(\%)$ & $\begin{array}{c}\mathbf{n}^{\mathbf{0}} \\
\text { abs. }\end{array}$ & $(\%)$ & $\begin{array}{c}\mathbf{n}^{\mathbf{0}} \\
\text { abs. }\end{array}$ & $(\%)$ \\
\hline Norte & - & - & - & - & 3 & 100,0 & $\mathbf{3}$ & $\mathbf{1 0 0 , 0}$ \\
Nordeste & 1 & 5,6 & - & - & 17 & 94,4 & $\mathbf{1 8}$ & $\mathbf{1 0 0 , 0}$ \\
Sudeste & 2 & 10,5 & 2 & 10,5 & 15 & 79,0 & $\mathbf{1 9}$ & $\mathbf{1 0 0 , 0}$ \\
Sul & - & - & - & - & 5 & 100,0 & $\mathbf{5}$ & $\mathbf{1 0 0 , 0}$ \\
\hline
\end{tabular}

Fonte: Câmara dos Deputados (Repertório Biográfico) e Senado Federal (Dados Biográfi$\cos )$.

Interessante assinalar que, segundo os dados recolhidos em nossas entrevistas com os membros da elite parlamentar do pósConstituinte, a posse de diploma superior não era compartilhada 
pela maioria dos pais desses políticos. De fato, $60 \%$ dos ascendentes diretos de tais parlamentares não detinham nível superior. Entretanto, todos os congressistas cujos pais dispunham de diploma universitário (40\%), correspondiam, em sua maioria, àqueles que admitiram ser o exercício parlamentar uma tradição em suas famílias. ${ }^{8}$ Tais informações reforçam a tese de que o elitismo presente na formação educacional dos parlamentares brasileiros é uma característica que vem sendo reproduzida ao longo da história política nacional. Não obstante, se há quase que uma obrigatoriedade em se dispor de titulação universitária para vir a ser congressista e, mais ainda, para participar da elite parlamentar, isso não significa ausência de espaços para a ascensão daqueles que não se enquadram nessa condição, ou mesmo para aqueles que, em suas biografias, não apresentam tradição familiar relacionada ao fazer política e/ou ao "saber formal".

Quanto aos tipos de profissão predominantes entre os membros da elite parlamentar (Tabelas 4A e 4B), verifica-se a supremacia dos advogados (38,3\% e 33,3\%), tal como observado entre os congressistas de modo geral (Tabela 5C, ver Anexo). Contudo, essa preponderância foi bem mais acentuada no interior da elite do que no Congresso Nacional (em média, 22,7\%), chegando a atingir percentual ainda mais elevado $(55,3 \%)$, quando se considera a totalidade dos parlamentares que dispunham de diploma de bacharel em Direito, apesar de não terem exercido prioritariamente a profissão de advogado.

O bacharelismo não é, de forma alguma, um traço recente na vida política brasileira. Desde o Império, observa-se, na elite política do País, a supremacia de pessoas cuja formação comum em Direito fortaleceu sobremaneira a construção de certa homogeneidade interna, tanto em termos ideológicos quanto de interesses e habilidades. ${ }^{8}$

Ademais, o bacharelismo encontra, no Brasil, terreno fértil de propagação entre os políticos, por ser a síntese do que, certa vez, 
Sérgio Buarque de Hollanda (1995, p. 156-157) nominou como "nossa inclinação geral pelas profissões liberais", a qual cumpre com a dupla tarefa de ornamentação e independência individual. Isso decorre, segundo o autor, do excessivo personalismo existente na sociabilidade brasileira, o qual, nascido na órbita do doméstico, manifesta-se como resistência a qualquer lei geral que o contrarie e, igualmente, como incapacidade de nos aplicarmos em objetivos exteriores a nós mesmos. Tais manifestações encontram-se expressas na satisfação com o saber aparente, desvinculado de um fim exterior e procurado enquanto elemento de prestígio para quem o detém.

\section{Tabela 4A - Composição da elite, por profissão da elite, por profissição e região elitoral - Brasil - 1987 a 1995}

\begin{tabular}{|c|c|c|c|c|c|c|c|c|}
\hline \multirow{3}{*}{ Profissão } & \multicolumn{8}{|c|}{ Região eleitoral } \\
\hline & \multicolumn{2}{|c|}{ Norte } & \multicolumn{2}{|c|}{ Nordeste } & \multicolumn{2}{|c|}{ Sudeste } & \multicolumn{2}{|c|}{ Sul } \\
\hline & $\begin{array}{l}\mathrm{n}^{\mathrm{o}} \\
\text { abs. }\end{array}$ & $(\%)$ & $\begin{array}{c}\mathrm{n}^{\mathrm{o}} \\
\mathrm{abs} \text {. }\end{array}$ & $(\%)$ & $\begin{array}{c}\mathrm{n}^{\mathrm{o}} \\
\mathrm{abs} .\end{array}$ & $(\%)$ & $\begin{array}{c}\mathrm{n}^{\mathrm{o}} \\
\mathrm{abs} \text {. }\end{array}$ & $(\%)$ \\
\hline Advogado & 1 & 33,3 & 6 & 42,8 & 8 & 40,0 & 3 & 30,0 \\
\hline Professor & - & - & 1 & 7,1 & 5 & 25,0 & 2 & 20,0 \\
\hline Empresário & - & - & 3 & 21,4 & - & - & 2 & 20,0 \\
\hline Economista & - & - & 1 & 7,1 & 3 & 15,0 & 1 & 10,0 \\
\hline Jornalista & - & - & 1 & 7,1 & - & - & 2 & 20,0 \\
\hline Médico & 1 & 33,3 & 1 & 7,1 & - & - & - & - \\
\hline Ruralista & - & - & 1 & 7,1 & 1 & 5,0 & - & - \\
\hline Metalúrgico & - & - & - & - & 1 & 5,0 & - & - \\
\hline Militar & 1 & 33,3 & - & - & - & - & - & - \\
\hline Bancário & - & & - & - & 1 & 5,0 & - & \\
\hline $\begin{array}{l}\text { Administrador } \\
\text { de empresa }\end{array}$ & - & - & - & - & 1 & 5,0 & - & - \\
\hline Total & 3 & 100,0 & 14 & 100,0 & 20 & 100,0 & 10 & 100,0 \\
\hline
\end{tabular}

Fonte: Câmara dos Deputados (Repertório Biográfico) e Senado Federal (Dados Biográficos).

Ainda que seja um traço marcante da política brasileira e exerça importância fundamental na definição do perfil ideológico e comportamental de nossos políticos, não resta dúvida de que a 
proximidade das profissões liberais - em especial a dos advogados-, com a vida parlamentar, não é privativa dessa sociedade. Weber (1993, p. 78) já apontava que não era casual a importância dos advogados na política ocidental, após o advento dos partidos políticos.

\section{Tabela 4B - Composição da elite, por profissão e região eleitoral - Brasil - 1995 a 2004}

\begin{tabular}{|c|c|c|c|c|c|c|c|c|}
\hline \multirow{3}{*}{ Profissão } & \multicolumn{8}{|c|}{ Região eleitoral } \\
\hline & \multicolumn{2}{|c|}{ Norte } & \multicolumn{2}{|c|}{ Nordeste } & \multicolumn{2}{|c|}{ Sudeste } & \multicolumn{2}{|c|}{ Sul } \\
\hline & $\begin{array}{c}\mathrm{n}^{\mathrm{o}} \\
\text { abs. }\end{array}$ & $(\%)$ & $\begin{array}{c}\mathrm{n}^{\mathrm{o}} \\
\text { abss. }\end{array}$ & $(\%)$ & $\begin{array}{c}\mathrm{n}^{\mathrm{o}} \\
\text { abs. }\end{array}$ & $(\%)$ & $\begin{array}{c}\mathrm{n}^{\circ} \\
\text { abs. }\end{array}$ & $(\%)$ \\
\hline Advogado & 2 & 66,7 & 5 & 27,8 & 5 & 26,3 & 3 & 60,0 \\
\hline Empresário & - & - & 2 & 11,1 & - & - & - & - \\
\hline Engenheiro & - & - & 4 & 22,2 & 2 & 10,5 & - & - \\
\hline Médico & - & - & 3 & 16,7 & 1 & 5,3 & - & - \\
\hline Jornalista & - & - & - & - & 1 & 5,3 & - & - \\
\hline Professor & 1 & 33,3 & - & - & 3 & 15,8 & 1 & 20,0 \\
\hline Economista & - & - & 1 & 5,6 & 2 & 10,5 & 1 & 20,0 \\
\hline Bancário & - & - & - & - & 1 & 5,3 & - & - \\
\hline Administrador de empresas & - & - & 1 & 5,6 & 2 & 10,5 & - & - \\
\hline Delegado & - & - & 1 & 5,6 & - & - & - & - \\
\hline Analista Financeiro & - & - & - & - & 1 & 5,3 & - & - \\
\hline Metalúrgico & - & - & - & - & 1 & 5,3 & - & - \\
\hline Enfermeiro & - & - & 1 & 5,6 & & & & \\
\hline Total & 3 & 100 & 18 & 100,0 & 19 & 100 & 5 & 100,0 \\
\hline
\end{tabular}

Fonte: Câmara dos Deputados (Repertório Biográfico) e Senado Federal (Dados Biográfi$\cos )$.

Comparativamente ao Congresso, nota-se, também, na composição profissional da elite maior percentual de parlamentares cuja profissão primordial era a de professor: $17 \%$ e $11,1 \%$, contra $7,4 \%$, em média, no Congresso Nacional. Por outro lado, na elite, verifica-se uma participação menos expressiva dos representantes diretos de interesses mais organizados socialmente, como, por exemplo, os empresários (10,6\% e 4,4\% dos membros da elite e, em média, $13,7 \%$ do Congresso Nacional) e os ruralistas $(4,3 \%$ 
da elite, nas $48^{\mathrm{a}}$ e $49^{\mathrm{a}}$ legislaturas, e sem representantes nas $50^{\mathrm{a}}$, $51^{\mathrm{a}}$ e $52^{\mathrm{a}}$, contra $7,9 \%$, em média, do Congresso). Merece ainda destaque a presença crescente e acentuada de profissionais liberais, como médicos, engenheiros e economistas na elite. Entre 1989 e 1994, eles representavam 14,8\% dos membros da elite, passando a corresponder, entre 1995 e 2004, a 31,1\% desses congressistas. O crescimento das profissões liberais acima citadas também se verifica no Congresso Nacional, porém, em proporção bem mais reduzida (20\%). Em contraposição, a ausência de servidores públicos na elite é digna de registro, assim com a sua fraca presença no Congresso Nacional (média de 3,9\%).

As Tabelas 4A e 4B revelam algumas distinções quanto às principais profissões dos parlamentares da elite de acordo com a sua região eleitoral. Em todas as regiões e legislaturas, a profissão de advogado foi predominante entre os membros da elite. O mesmo não se verifica, todavia, em relação à segunda profissão mais observada entre esses congressistas. Com efeito, enquanto que para os representantes nordestinos a profissão de empresário foi a segunda mais incidente, entre 1987 e 1994, e a de engenheiro, entre 1995 e 2004, para os do Sudeste e Sul foi a de professor. Importa ressaltar que, se entre os parlamentares nordestinos da elite a presença de empresários foi considerável (21,4\% e 11,2\%), entre os membros do Sudeste ela inexistiu. Isso indica que a representação dos interesses desse segmento social dentro da bancada nordestina era feita de forma direta, ao contrário do que acontecia na bancada do Sudeste, onde ela era intermediada por outros agentes.

A concomitância da carreira parlamentar com o exercício de outra profissão foi admitida - ainda que com certo desconforto, à exceção dos acadêmicos - pela maior parte dos entrevistados da elite $(73,3 \%)$. Não obstante, o que se constata é que para alguns desses parlamentares, a duplicidade profissional teve curta duração, abrangendo apenas os primeiros anos de mandato, enquanto que 
para outros, a referida simultaneidade nunca deixou de existir, ou manteve-se por muito tempo. A explicação para essa situação encontra-se diretamente relacionada às dificuldades de reeleição, as quais assombram não só os congressistas brasileiros, mas também os parlamentares de todo o mundo. Em verdade, as incertezas quanto aos resultados eleitorais das próprias candidaturas estimulam sobremaneira a manutenção dos vínculos entre os parlamentares e suas outras atividades profissionais. Além disso, é imperioso observar que muitos se aproveitam da posição privilegiada no Congresso para realizar negócios rentáveis com o mercado.

A ocupação de cargos públicos constitui outro indicador importante para a definição do perfil da elite parlamentar. Tomandose os dados das Tabelas 5A e 5B, pode-se verificar que a ocupação de cargos públicos entre os membros da elite $(78,7 \%$ e $82,2 \%)$ foi bem superior àquela observada, em média (57\%), entre os parlamentares do Congresso Nacional (Tabela 6C, ver Anexo). Mais do que isso, na elite, tal ocupação concentrou-se fundamentalmente nos cargos localizados no topo da administração pública (ministros, secretários de governo, presidente/superintendente/diretor de empresa pública). Isso revela uma conexão direta, embora não obrigatória, entre a ocupação de cargos públicos, especialmente os de grande expressão, e a participação na elite parlamentar.

A ocupação de cargos públicos (federais, estaduais, ou municipais) por parlamentares no decorrer de sua vida pública não é uma característica recente da trajetória política dos congressistas brasileiros. Como aponta Carvalho, no Império configurou-se com certa freqüência uma verdadeira simbiose entre a cúpula da burocracia do Estado e a elite política. O exercício de cargos públicos era, pois, etapa fundamental do treinamento da elite política, assim como a circulação de seus membros entre os principais postos dos três poderes. Parece que ainda hoje se mantêm presentes, na ocupação de cargos públicos por parlamentares, as funções de treinamento e 


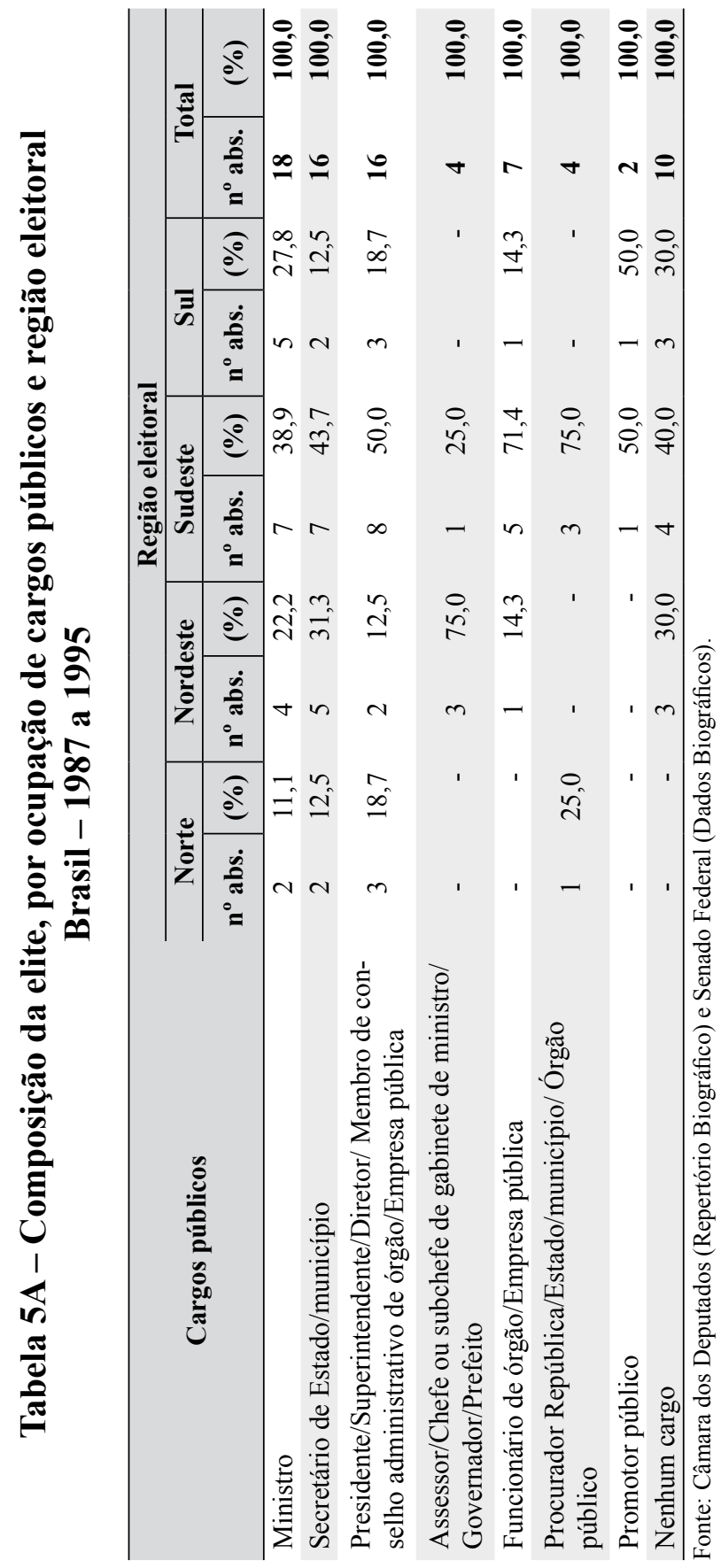




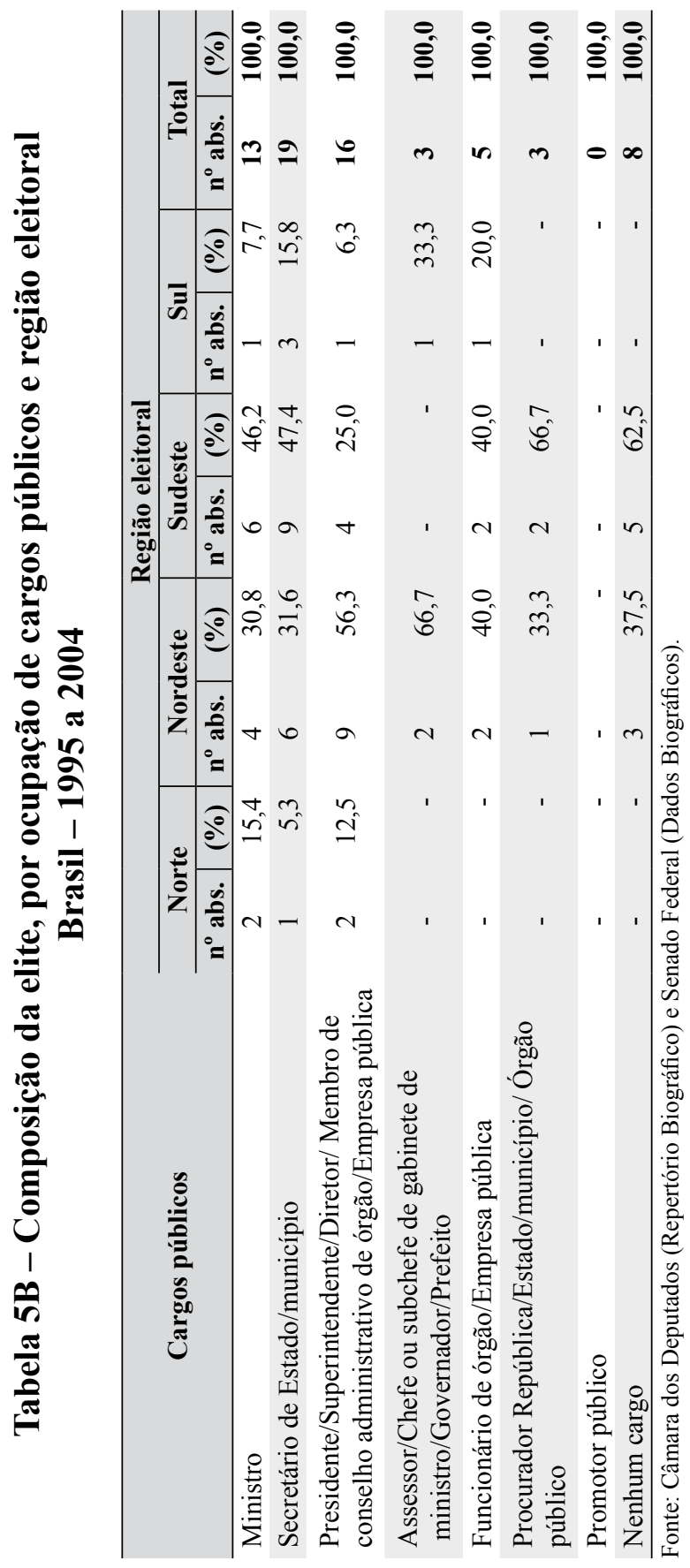


circulação dos membros da elite política vigentes desde o Império. Mesmo com o advento da República e o sufrágio universal, a conquista de cargos públicos por membros do Legislativo, ou por aqueles que tenham a pretensão de vir a ser, é deveras importante, seja como via para aquisição de um mandato parlamentar, seja como instrumento para a sua renovação. A visibilidade que um cargo de destaque na hierarquia do serviço público propicia ao seu ocupante, aliada aos recursos de poder ${ }^{9}$ inerentes a essas posições, fazem com que a participação direta nos altos escalões da burocracia do Estado - em quaisquer de suas esferas -, se apresente como um dos mais tradicionais e eficientes mecanismos empregados na política brasileira para a consecução de mandatos parlamentares. Em sentido inverso, a detenção de mandato parlamentar facilita muitas vezes a conquista de postos de prestígio na hierarquia da administração pública. A alocação de parlamentares na burocracia do Estado vai depender do tipo de coalizão partidária estabelecida no âmbito municipal, estadual e/ou federal, além de contar com a experiência do congressista no trato com o Executivo e o seu conhecimento acerca dos trâmites das ações no interior deste poder.

As Tabelas 5A e 5B também informam que os representantes do Sudeste foram os que mais conquistaram cargos públicos considerados “top de linha". Esse dado tende a reforçar a suposição de uma maior concentração de saber especializado entre os membros do Sudeste na elite. Tal tendência já se mostrava presente quando da verificação do significativo percentual de professores universitários entre os profissionais representantes da região. Essa constatação estende-se, de certa forma, aos congressistas sulistas, visto que - a despeito de contarem com número inferior de representantes na elite, comparativamente aos do Nordeste e do Sudeste - conquistaram vários postos de ministro, secretários de estado/município e presidente/diretor de empresas públicas. 
Se entre os parlamentares do Sudeste se encontram aqueles que mais ocuparam cargos públicos de relevância no Executivo brasileiro, entre eles também estão os que majoritariamente não ocuparam nenhum cargo público ao longo de sua vida política. Em outros termos, cerca de $23 \%$ dos membros da elite do Sudeste construíram sua vida pública à margem do Poder Executivo em todas as suas instâncias. A predominância de profissionais liberais entre os parlamentares da elite do Sudeste é um elemento explicativo importante dessa situação, entretanto, crê-se que existam, no seio da elite, modelos distintos de trajetórias políticas em termos regionais.

Tal argumento se fortalece quando se atenta para o tipo de participação dos representantes nordestinos na ocupação de cargos públicos, dado que, apesar de sua expressiva participação nos cargos considerados "top de linha", eles foram os que, preponderantemente, ocuparam postos de menor importância na estrutura hierárquica dos governos, mas que gravitavam em torno dos chefes dos Executivos em suas três dimensões (assessor/chefe ou subchefe de gabinete).

Interessante assinalar que a ocupação de cargos públicos mais diretamente vinculados ao poder local $/$ regional $^{9}$ foi realizada pela totalidade dos representantes nordestinos e nortistas da elite, anteriormente ao seu ingresso no Congresso Nacional. Já entre os parlamentares das demais regiões, as trajetórias foram um pouco mais diversificadas: se, para muitos dos representantes do Sudeste, ${ }^{10}$ a conquista dos referidos postos foi também antecedente à vida parlamentar no âmbito federal, para outros da mesma região, e para a totalidade dos sulistas que assumiram tais cargos, as ocupações só se efetivaram ao longo de suas carreiras no Congresso Nacional. Isso quer dizer que, para uma parcela dos representantes do Sudeste e para os do Sul na elite, a ocupação de cargos públicos vinculados aos poderes locais e regionais (particularmente, às secretarias de governo) apresentava-se ainda atrativa ao desenvolvimento de 
suas carreiras políticas. De outra feita, entre os representantes do Norte e Nordeste, o retorno à ocupação de cargos na administração pública só se mostrou atraente quando relacionado a posições "top de linha" no âmbito federal. Daí compreende-se, em parte, a elevada incidência - sobretudo entre os parlamentares nordestinos da elite - na ocupação de cargos-chave do Poder Legislativo, revelando um direcionamento mais intenso de suas carreiras para o interior do Parlamento.

De forma geral, a ocupação de cargos públicos foi concebida positivamente pelos membros da elite. Segundo os entrevistados, a circulação de políticos entre o Executivo e o Legislativo revelava-se, de um lado, uma experiência enriquecedora e até mesmo necessária, principalmente, para aqueles cujas carreiras políticas só se fizeram dentro do Legislativo, sem vivência, portanto, das dificuldades e limitações existentes na execução das políticas públicas. De outro lado, o exercício parlamentar era visto como percurso indispensável para a aquisição do manejo profissional da arte da negociação política.

A ocupação de cargos importantes na estrutura organizacional do Congresso Nacional é também uma das principais vias que possibilitam a ascensão de certos congressistas à elite do Parlamento brasileiro. Entre esses postos, destacam-se aqueles que compõem as mesas diretoras da Câmara e do Senado, especialmente as presidências e as primeiras secretarias, as lideranças partidárias e os cargos-chave nas comissões permanentes, especiais e parlamentares de inquérito.

As mesas diretoras de ambas as Casas são constituídas por sete parlamentares cada uma, incluindo: o presidente, dois vicepresidentes e quatro secretários. As eleições para as mesas são realizadas de dois em dois anos, sendo vedada a recondução de seus membros para os mesmos cargos no período subseqüente. 
De acordo com os regimentos internos da Câmara e do Senado, a composição das respectivas mesas deve, na medida do possível, refletir a configuração partidária existente em cada Casa, cabendo ao maior partido a indicação da presidência.

Tomadas isoladamente, as presidências das mesas diretoras são as posições mais importantes do Parlamento. Ao presidente compete a coordenação dos trabalhos legislativos da Casa, sendo o seu representante-mor quando ela se pronuncia coletivamente no âmbito nacional e internacional. Na linha de sucessão do presidente da República, imediatamente após o vice-presidente, encontra-se o presidente da Câmara, seguido pelo presidente do Senado.

Também as primeiras secretarias das mesas têm sua relevância, na medida em que os titulares dos cargos são os responsáveis pelo gerenciamento dos serviços administrativos das Casas, tendo sob seu controle vultosos recursos relacionados à contratação e supervisão de milhares de funcionários, à manutenção dos recursos físicos e à contratação de serviços.

Os líderes partidários assumem, junto com as presidências das mesas, a definição da agenda do Legislativo. Outrossim, dispõem de amplas e importantes prerrogativas que transcendem a sua enorme influência na organização e tramitação dos trabalhos no Congresso Nacional. Seus poderes, ponderados de acordo com o tamanho de suas bancadas, incidem não somente no direcionamento de seus liderados a respeito das proposições sob deliberação no Congresso, como também na definição da participação e substituição dos membros de seus partidos nas comissões, delegações e em outras tarefas.

Na estrutura das comissões temáticas da Câmara e do Senado, dois são os cargos a assumir destaque: a presidência e a relatoria. Por força regimental, os presidentes das comissões permanentes dispõem de mandato de um ano na Câmara e de dois anos no Senado. 
A eles compete a coordenação de todos os trabalhos internos a esse instituto, assim como a indicação dos relatores das matérias sujeitas a parecer. Seguindo o critério da proporcionalidade partidária, temse que os maiores partidos detêm a supremacia na ocupação desses cargos em ambas as Casas.

Destaque-se, no entanto, que, a depender da matéria e do tipo de tramitação, a relatoria pode tornar-se a função mais importante de uma comissão. O relator é o responsável pela elaboração de parecer, o qual será objeto de deliberação da comissão ou do plenário. É a partir do trabalho realizado pelo relator que se pautam as discussões e as votações das matérias, havendo, portanto, grande preocupação dos partidos em controlar a relatoria das principais proposições em tramitação. Geralmente, os relatores são membros do mesmo partido dos presidentes das comissões vigendo, por conseguinte, a supremacia nesses postos dos representantes das grandes agremiações.

Quanto à definição da autoria das proposições, sabe-se que, de acordo com a Constituição Federal (art. 61, $\S 2^{\circ}$ ), a iniciativa das leis complementares e ordinárias cabe a qualquer membro ou comissão do Congresso Nacional, ao presidente da República, ao Supremo Tribunal Federal, aos Tribunais Superiores, ao procurador-geral da República e aos cidadãos. Contudo, dependendo da natureza e relevância da matéria, a definição de sua autoria surge como o resultado de um acirrado jogo de interesses, no qual muitas vezes o congressista-autor é apenas um nome, muitas vezes sem "peso" político, tomado por "empréstimo", de forma a abrigar propostas de grupos específicos, ou a funcionar como "ventríloquo" de lideranças políticas que preferem - ou precisam - manter-se no anonimato. Por certo, a autoria de proposições importantes, tal como a relatoria, encontra-se muitas vezes vinculada à criatividade e a saberes específicos dominados por certos parlamentares, podendo também redundar de compromissos firmados por esses com suas bases 
eleitorais, e que devem ser formalizados em projetos de lei de sua iniciativa.

A ocupação de cargos-chave na estrutura organizacional da Câmara dos Deputados e do Senado Federal fez parte da trajetória política da grande maioria (89,4\%) dos membros da elite entre 1989 e 1995 e da totalidade de seus membros nas legislaturas seguintes. Entre os principais cargos ocupados, assume posição de destaque o de líder partidário (42,5\% e 73,3\%), porque, além de garantir aos seus ocupantes uma série de prerrogativas no processo legislativo, propicia, especialmente aos representantes dos principais partidos, ampla visibilidade intra e extramuros do Congresso.

As Tabelas 6A e 6B revelam que, dos membros da elite que conquistaram cargos nas mesas diretoras da Câmara ou do Senado, a maioria (respectivamente 55,5\% e 57,1\%) eram representantes do Nordeste ao longo de todas as legislaturas. A ocupação majoritária de representantes nordestinos e governistas na composição da mesa é uma tradição já apontada por Baaklini (1993, p. 60-68), em seu livro sobre a caracterização e o funcionamento do Congresso Nacional durante o regime militar. De acordo com o autor, entre os anos de 1970 e 1984, os parlamentares nordestinos e do Sudeste ocuparam, respectivamente, $40 \%$ e $32 \%$ dos cargos da mesa diretora da Câmara e 51,7\% e 12,1\% da mesa do Senado, no período de 1970 a 1986.

Comparando tais dados com aqueles disponíveis para o período de 1989 a 2004, verifica-se a reprodução, no pós-Constituinte, da supremacia dos representantes nordestinos na composição das mesas diretoras de ambas as Casas. Na Câmara, entre 1989 e 1994, $52,4 \%$ dos cargos foram ocupados por representantes nordestinos e $23,8 \%$ por representantes do Sudeste, sendo que os dois postos mais importantes, a presidência e a $1^{\mathrm{a}}$ secretaria, foram conquistados, em sua maioria, por parlamentares nordestinos (duas presidências e duas primeiras secretarias). No Senado, a participação dos 


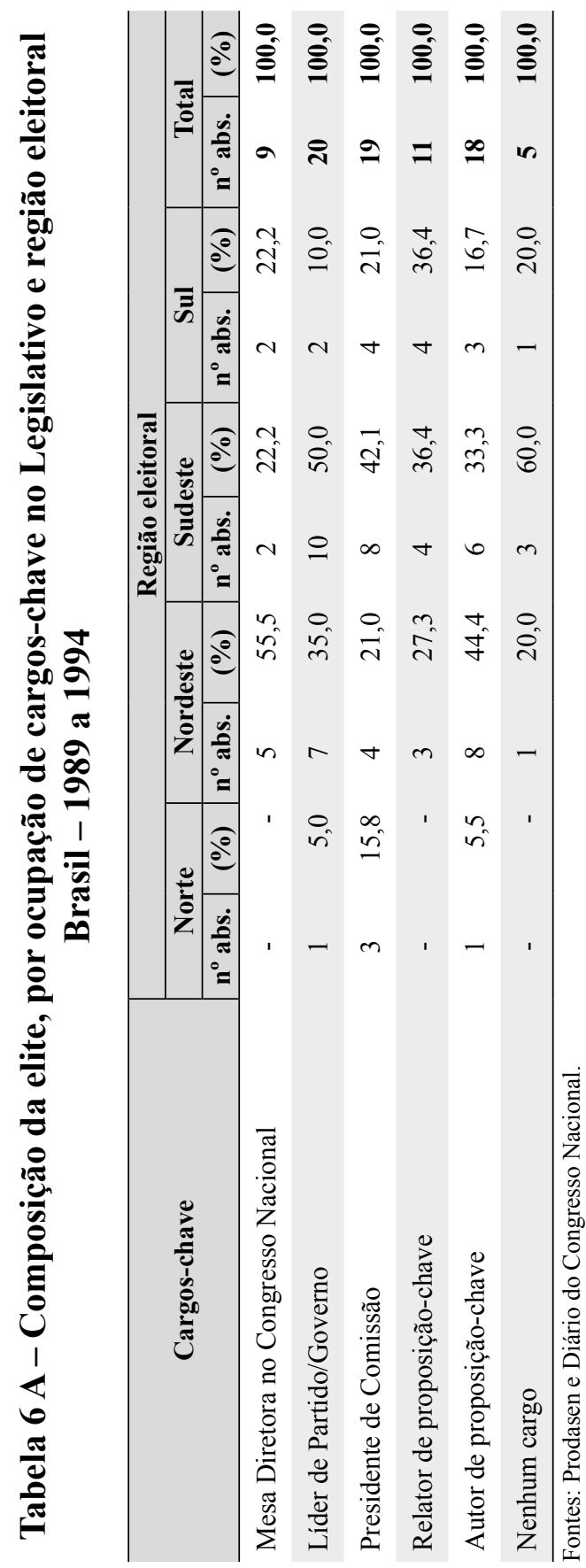




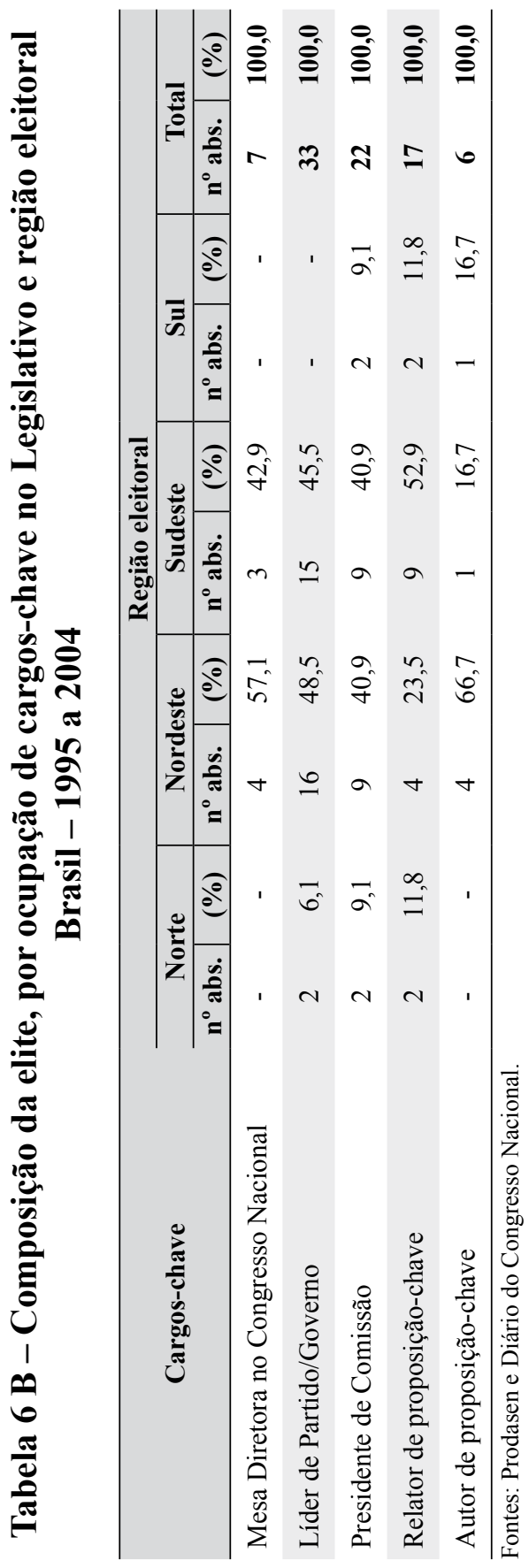


nordestinos na mesa diretora foi mais reduzida $(28,6 \%)$, assim como a dos representantes do Sudeste (9,5\%). No entanto, registrou-se a prevalência dos primeiros nos cargos de presidente (duas vezes). Entre 1995 e 2004, mantém-se a preponderância dos nordestinos nas mesas diretoras de ambas as Casas. Na Câmara, esses parlamentares ocuparam 57,1 dos cargos da mesa, sendo que uma presidência e todas as primeiras secretarias. Os congressistas do Sudeste ocuparam, por sua vez, $20 \%$ dos postos da mesa diretora, mas assumiram quatro presidências. Nas mesas diretoras do Senado, a supremacia dos nordestinos foi muito expressiva, pois eles ocuparam $48,6 \%$ dos cargos e quatro das cinco presidências e secretarias configuradas durante esses anos.

O predomínio dos representantes do Sudeste na conquista dos cargos de líderes partidários e de governo (50\%) entre os membros da elite parlamentar, de 1989 a 1994, não se repetiu nas legislaturas posteriores. Como se verifica na Tabela 6B, os representantes nordestinos assumiram 48,5\% dos cargos, enquanto que os do Sudeste ocuparam 45,5\% dessas posições. Interessante observar que, se tomarmos todas as lideranças partidárias e de governo que se configuraram no Congresso Nacional ao longo desses anos-inclusive as dos pequenos partidos que, em determinadas ocasiões, atingiram número mínimo de representantes para constituírem liderança veremos que a superioridade numérica dos representantes do Sudeste perdurou. Em outras palavras, durante as $50^{\mathrm{a}}, 51^{\mathrm{a}}$ e $52^{\mathrm{a}}$ legislaturas, dos líderes partidários e de governo, 38,4\% eram congressistas do Sudeste, $34,9 \%$ do Nordeste, $11,6 \%$ do Norte, $8,1 \%$ do Centro-Oeste e $7 \%$ do Sul. Nota-se que a ausência de membros da elite do Sul na condição de líderes partidários e de governo reflete sua reduzida participação nesses cargos ao longo do período.

Se compararmos esses dados com aqueles levantados por Baaklini (1993, p. 111) durante o período militar, veremos também que, na ocupação desses postos no Congresso, houve o 
predomínio dos parlamentares representantes do Sudeste. Segundo o autor, $48 \%$ das lideranças partidárias na Câmara foram ocupadas por congressistas dessa região e $13 \%$ por nordestinos, enquanto que no Senado, 43,8\% das lideranças partidárias foram preenchidos por membros do Sudeste e 31,3\% por representantes do Nordeste.

Quanto à participação majoritária dos representantes do Sudeste da elite na ocupação das presidências das comissões $(42,1 \%$ e 40,9\%), cabe apontar que tal supremacia se reproduz na Câmara desde a ditadura militar até o pós-Constituinte. Já, no Senado, registrou-se, mais uma vez, a preponderância da presença nordestina na ocupação dos cargos-chave do Legislativo. Considerando-se a distribuição regional das presidências das comissões permanentes, ao longo do regime militar, tem-se que $40,8 \%$ dessas posições foram conquistadas na Câmara por membros do Sudeste, 34\% por representantes do Nordeste e $16,5 \%$ por parlamentares do Sul. No Senado, o quadro se diferencia, ocupando os nordestinos $44,8 \%$ das presidências, os do Sudeste $23,2 \%$ e os do Sul $12 \%$.

No que diz respeito aos postos de relatoria das principais proposições conquistados pelos membros da elite, entre os anos de 1989 e 1994, merece destaque a participação mais freqüente dos membros do Sudeste e do Sul nessa atividade. Em conjunto, eles detiveram $73 \%$ dos cargos de relator. Nas legislaturas seguintes, a participação dos representantes do Sudeste nesses cargos foi ainda mais expressiva $(52,9 \%)$ e a dos sulistas refletiu sua queda no número de participantes na elite ao longo do período $(11,8 \%)$.

As Tabelas 6A e 6B apontam, ainda, que uma parcela significativa da elite parlamentar assumiu diretamente a autoria de projetos-chave $(38,3 \%)$ durante os anos de 1989 a 1994, embora tenha tido sua participação reduzida nesses cargos nas legislaturas posteriores $(13,3 \%)$. Exerceram primordialmente essa função na elite, os seus representantes nordestinos (44,4\% e 66,7\%), seguidos 
à distância pelos parlamentares do Sudeste $(33,3 \%$ e $16,7 \%)$ e do Sul (16,7\% em todas as legislaturas). A Tabela $6 \mathrm{~A}$ permite verificar também que os parlamentares que não direcionaram sua carreira para a ocupação de cargos-chave do Legislativo, e/ou não tiveram oportunidade para tanto, encontravam-se majoritariamente entre os representantes do Sudeste. Em outros termos, de 1989 a 1994, 15\% dos membros do Sudeste pertencentes à elite não ocuparam nenhum cargo de importância na estrutura organizacional do Congresso Nacional e, mesmo assim, garantiram sua inserção nesse grupo.

De modo sumário, depreende-se das informações acerca da trajetória dos parlamentares da elite na ocupação dos cargos-chave do Legislativo: primeiramente, que a conquista de tais posições mostra-se deveras importante para a ascensão da grande maioria desses congressistas à condição de elite; em segundo lugar, no que alude à construção das carreiras políticas dos membros da elite no interior do Congresso, constatam-se distinções quanto aos caminhos trilhados por esses atores sociais. Mais do que isso, a definição dos caminhos a serem trilhados por tais congressistas no Parlamento parece ser influenciada pela origem regional de sua representação, seja como fator a influir no que esses políticos consideram e prestigiam enquanto espaços de poder dentro do Congresso Nacional, seja como aspecto levado em conta na distribuição dos cargos-chave do Legislativo.

Embora na política seja impossível determinar todos os aspectos que envolvem os resultados das negociações, há que se admitir que a reprodução contínua e de longa data no favorecimento a parlamentares de certas regiões na ocupação de determinados cargos-chave do Congresso Nacional não pode ser encarada como mera coincidência, ainda que esta possa eventualmente ocorrer. De outra maneira, o que se ressalta é que, se a distribuição regional dos cargos de liderança na Câmara e no Senado - ainda que de 
forma distinta entre si e a despeito das profundas transformações na ordem política nacional - manteve-se relativamente constante, desde a ditadura militar até o pós-Constituinte, é porque o local da representação do parlamentar tem importância na definição de quem serão os ocupantes dos cargos-chave do Legislativo e há o privilégio a determinadas regiões na distribuição desses postos de liderança. Tal situação pode estar relacionada a uma série de fatores, os quais se vinculam aos interesses dos partidos em prestigiar seus principais redutos eleitorais, ao direcionamento distinto e culturalmente influenciado das carreiras desses políticos no interior do Parlamento e até mesmo à convicção, presente no imaginário da maioria desses parlamentares, quanto à existência de diferenciações marcantes entre as práticas políticas dos congressistas das diferentes regiões brasileiras configurando, portanto, perfis mais "talhados" para o exercício de determinadas lideranças. ${ }^{11}$

Interessante observar que, apesar de a maioria absoluta dos membros da elite parlamentar ter ocupado cargos-chave do Congresso Nacional no pós-Constituinte, existe uma clara divisão entre os entrevistados quanto à real importância dessa conquista para a ascensão de um parlamentar à elite. Para muitos, a competência e o talento individual aliados a um trabalho árduo no Parlamento são as condições fundamentais para que um congressista tenha assento na elite, enquanto que para outros, além dos condicionantes acima, tem-se na conquista de cargos-chave um fator que não só auxilia, mas acelera tal ingresso. Esta última percepção, de acordo com survey realizado por Figueiredo e Limongi (1995), parece ser também a dominante entre os membros do Parlamento. Segundo os autores, é consenso entre os deputados que a ocupação de cargoschave mostra-se decisiva para a definição de quem tem poder de influência nas decisões legislativas, dispondo os parlamentares individualmente de poucos recursos para intervir de forma intensa no processo legislativo. Quanto à perspectiva dos que não valorizam 
sobremaneira a ocupação de cargos-chave como forma de ascensão à elite, pode-se encontrar aí embutida não só a percepção de que a conquista de postos importantes no Legislativo não garante sozinha o ingresso de um congressista nesse restrito grupo - o que é verdade - mas, igualmente, envolve outra dimensão, relacionada com o personalismo arraigado na cultura política brasileira e facilmente observável no universo parlamentar.

A ocupação de cargos eletivos é outro indicador relevante para a caracterização da trajetória política dos membros da elite parlamentar. Os congressistas do pós-Constituinte não seguiram uma rota linear quanto à ocupação hierárquica dos cargos eletivos. (Tabela 7C, ver Anexo) Da mesma forma, observa-se, também, na elite, tal descontinuidade. Entretanto, há no seio desta (Tabelas 7A e 7B), em comparação com o Congresso, maior incidência de parlamentares que conquistaram cargos tidos como superiores na hierarquia do Executivo e do Legislativo.

\section{Tabela 7A - Composição da elite, por ocupação de cargos eletivos e região eleitoral - Brasil - 1987 a 1995}

\begin{tabular}{|c|c|c|c|c|c|c|c|c|c|c|}
\hline \multirow{3}{*}{$\begin{array}{l}\text { Cargos } \\
\text { eletivos }\end{array}$} & \multicolumn{10}{|c|}{ Região eleitoral } \\
\hline & \multicolumn{2}{|c|}{ Norte } & \multicolumn{2}{|c|}{ Nordeste } & \multicolumn{2}{|c|}{ Sudeste } & \multicolumn{2}{|c|}{ Sul } & \multicolumn{2}{|c|}{ Total } \\
\hline & $\begin{array}{c}n^{0} \\
\text { abs. }\end{array}$ & $(\%)$ & $\begin{array}{c}n^{0} \\
\text { abs. }\end{array}$ & $(\%)$ & $\begin{array}{c}\mathrm{n}^{0} \\
\text { abs. }\end{array}$ & $(\%)$ & $\begin{array}{c}n^{0} \\
\text { abs. }\end{array}$ & $(\%)$ & $\begin{array}{c}n^{0} \\
\text { abs. }\end{array}$ & $(\%)$ \\
\hline Vereador & - & - & 2 & 18,2 & 6 & 54,5 & 3 & 27,3 & 11 & 100,0 \\
\hline $\begin{array}{l}\text { Deputado } \\
\text { estadual/ } \\
\text { distrital }\end{array}$ & 1 & 4,8 & 9 & 42,8 & 7 & 33,3 & 4 & 19,1 & 21 & 100,0 \\
\hline $\begin{array}{l}\text { Deputado } \\
\text { federal }\end{array}$ & 1 & 2,5 & 13 & 32,5 & 17 & 42,5 & 9 & 22,5 & 40 & 100,0 \\
\hline Senador & 2 & 11,8 & 5 & 29,4 & 7 & 41,2 & 3 & 17,6 & 17 & 100,0 \\
\hline Prefeito & 1 & 16,7 & 1 & 16,7 & 1 & 16,6 & 3 & 50,0 & 6 & 100,0 \\
\hline Governador & 1 & 14,3 & 4 & 57,1 & - & - & 2 & 28,6 & 7 & 100,0 \\
\hline Presidente & - & - & 1 & 100,0 & - & - & - & - & 1 & 100,0 \\
\hline
\end{tabular}

Fonte: Câmara dos Deputados (Repertório Biográfico) e Senado Federal (Dados Biográfi$\cos )$. 


\section{Tabela 7B - Composição da elite, por ocupação de cargos eletivos e região eleitoral - Brasil - 1995 a 2004}

\begin{tabular}{|c|c|c|c|c|c|c|c|c|c|c|}
\hline \multirow{3}{*}{$\begin{array}{l}\text { Cargos } \\
\text { eletivos }\end{array}$} & \multicolumn{10}{|c|}{ Região eleitoral } \\
\hline & \multicolumn{2}{|c|}{ Norte } & \multicolumn{2}{|c|}{ Nordeste } & \multicolumn{2}{|c|}{ Sudeste } & \multicolumn{2}{|c|}{ Sul } & \multicolumn{2}{|c|}{ Total } \\
\hline & $\begin{array}{c}n^{0} \\
\text { abs. }\end{array}$ & $(\%)$ & $\begin{array}{c}n^{0} \\
\text { abs. }\end{array}$ & $(\%)$ & $\begin{array}{c}n^{0} \\
\text { abs. }\end{array}$ & $(\%)$ & $\begin{array}{c}n^{0} \\
\text { abs. }\end{array}$ & $(\%)$ & $\begin{array}{c}n^{0} \\
\text { abs. }\end{array}$ & $(\%)$ \\
\hline Vereador & 2 & 25,0 & - & - & 4 & 50,0 & 2 & 25,0 & 8 & 100,0 \\
\hline $\begin{array}{l}\text { Deputado } \\
\text { estadual/dis- } \\
\text { trital }\end{array}$ & 1 & 6,7 & 8 & 53,3 & 4 & 26,7 & 2 & 13,3 & 15 & 100,0 \\
\hline $\begin{array}{l}\text { Deputado } \\
\text { federal }\end{array}$ & 2 & 5,3 & 15 & 39,5 & 19 & 50,0 & 2 & 5,3 & 38 & 100,0 \\
\hline Senador & 3 & 15,8 & 8 & 42,1 & 4 & 21,1 & 4 & 21,1 & 19 & 100,0 \\
\hline Prefeito & - & - & 5 & 55,6 & 2 & 22,2 & 2 & 22,2 & 9 & 100,0 \\
\hline Governador & 1 & 10,0 & 3 & 30,0 & 2 & 20,0 & 4 & 40,0 & 10 & 100,0 \\
\hline Presidente & - & - & 1 & - & - & - & - & - & 1 & 100,0 \\
\hline
\end{tabular}

Fonte: Câmara dos Deputados (Repertório Biográfico) e Senado Federal (Dados Biográfi$\cos )$.

De fato, a participação de parlamentares que foram governadores $(14,9 \%$ e $22,2 \%)$ e a dos que foram ou eram senadores na elite $(36,2 \%$ e $42,2 \%)$ foi bem maior do que aquela verificada, em média, entre os membros do Congresso Nacional (6\% e 14,9\%). A presença mais elevada, na elite, de parlamentares cuja trajetória política perpassa a ocupação de cargos dos altos escalões do Estado não causa estranhamento, tendo em vista que a própria condição de elite indica concentração de políticos com esse perfil. Todavia, merece destaque, a participação consideravelmente maior dos senadores na elite (30\%, entre 1989 e 1994 e 42,2\%, entre 1995 e 2004) do que a sua correspondente ocupação de cadeiras no Congresso (13,6\%). Esta situação relaciona-se, em parte, à própria expansão do número de sessões unicamerais após a Constituição de 1988. Lembre-se que, em virtude da necessidade de apreciação conjunta das leis orçamentárias, medidas provisórias e vetos presidenciais, veio se configurando participação mais ativa dos senadores nas grandes decisões nacionais, ultrapassando amplamente sua função primordial 
de revisores das proposições legislativas. Ademais, os senadores da República são, em sua maioria, políticos com ampla experiência parlamentar, o que acaba por torná-los hábeis conhecedores do processo legislativo, facilitando sua intervenção nos trabalhos das sessões do Congresso Nacional e na própria dinâmica do jogo político interno ao Parlamento.

Se a não-linearidade das trajetórias políticas dos membros da elite tanto no Executivo quanto no Legislativo revelou-se traço comum na carreira desses parlamentares, o direcionamento para a ocupação de determinados cargos eletivos apresentou diferenciações de acordo com a região de representação. Excetuandose os cargos de deputado federal e senador, os quais encontravamse muito influenciados pela ocupação legislativa dos membros da elite no momento da pesquisa, vale notar a diversidade regional na primazia da ocupação dos demais cargos. Com efeito, enquanto os representantes do Nordeste foram os que mais ocuparam cargos de deputado estadual $(42,8 \%$ e $53,3 \%)$ e governador $(57,1 \%$, nas $48^{\mathrm{a}}$ e $49^{\mathrm{a}}$ legislaturas), na atividade de vereança observou-se maior incidência dos membros do Sudeste $(54,5 \%$ e $50 \%)$ e, finalmente, nos cargos de prefeitos, encontravam-se em maioria, entre 1989 e 1994, os parlamentares da elite do Sul (50\%), sendo que, nas legislaturas seguintes, o percentual de sulistas que foram governadores é majoritário (40\%).

Curioso observar que, nas declarações dos entrevistados acerca da não-linearidade hierárquica de suas carreiras políticas, sobressaíram duas perspectivas bem distintas. Para uns, indistintamente entre os que seguiram e os que não seguiram tal percurso, a obediência à referida hierarquia seria garantia de um aprendizado mais profícuo da vida parlamentar. Para outros, a ocupação de determinados cargos eletivos seria absolutamente dispensável, considerando suas ambições políticas e mesmo seu perfil de atuação parlamentar. 


\section{Tabela 8A - Composição da elite, por região eleitoral e mandatos no Congresso Nacional - Brasil - 1987 a 1995}

\begin{tabular}{|c|c|c|c|c|c|c|c|c|c|c|}
\hline \multirow{3}{*}{$\begin{array}{l}\text { Região } \\
\text { eleitoral }\end{array}$} & \multicolumn{10}{|c|}{ Mandatos } \\
\hline & \multicolumn{2}{|c|}{ Um } & \multicolumn{2}{|c|}{ Dois } & \multicolumn{2}{|c|}{ Três } & \multicolumn{2}{|c|}{$\begin{array}{l}\text { Quatro ou } \\
\text { mais }\end{array}$} & \multicolumn{2}{|c|}{ Total } \\
\hline & $\begin{array}{c}n^{0} \\
\text { abs. }\end{array}$ & $(\%)$ & $\begin{array}{c}n^{0} \\
\text { abs. }\end{array}$ & $(\%)$ & $\begin{array}{c}n^{0} \\
\text { abs. }\end{array}$ & $(\%)$ & $\begin{array}{c}n^{0} \\
\text { abs. }\end{array}$ & $(\%)$ & $\begin{array}{c}n^{0} \\
\text { abs. }\end{array}$ & $(\%)$ \\
\hline Norte & 1 & 33,3 & 1 & 33,3 & 1 & 33,3 & - & - & 3 & 100,0 \\
\hline Nordeste & 1 & 7,1 & 5 & 35,7 & 3 & 21,4 & 5 & 35,7 & 14 & 100,0 \\
\hline Sudeste & 6 & 30,0 & 8 & 40,0 & 3 & 15,0 & 3 & 15,0 & 20 & 100,0 \\
\hline Sul & 1 & 10,0 & 6 & 60,0 & 3 & 30,0 & - & - & 10 & 100,0 \\
\hline Total & 10 & 21,3 & 19 & 40,4 & 10 & 21,3 & 8 & 17,0 & 47 & 100,0 \\
\hline
\end{tabular}

Fonte: Câmara dos Deputados (Repertório Biográfico) e Senado Federal (Dados Biográficos)

\section{Tabela 8B - Composição da elite, por região eleitoral e mandatos no Congresso Nacional - Brasil - 1995 a 2004}

\begin{tabular}{|c|c|c|c|c|c|c|c|c|c|c|}
\hline \multirow{3}{*}{$\begin{array}{l}\text { Região } \\
\text { eleitoral }\end{array}$} & \multicolumn{10}{|c|}{ Mandatos } \\
\hline & \multicolumn{2}{|c|}{ Um } & \multicolumn{2}{|c|}{ Dois } & \multicolumn{2}{|c|}{ Três } & \multicolumn{2}{|c|}{$\begin{array}{l}\text { Quatro } \\
\text { ou mais }\end{array}$} & \multicolumn{2}{|c|}{ Total } \\
\hline & $\begin{array}{c}\mathbf{n}^{\mathbf{0}} \\
\text { abs. }\end{array}$ & $(\%)$ & $\begin{array}{c}n^{0} \\
\text { abs. }\end{array}$ & $(\%)$ & $\begin{array}{c}n^{0} \\
\text { abs. }\end{array}$ & $(\%)$ & $\begin{array}{c}n^{0} \\
\text { abs. }\end{array}$ & $(\%)$ & $\begin{array}{c}n^{0} \\
\text { abs. }\end{array}$ & $(\%)$ \\
\hline Norte & 2 & 66,7 & 1 & 33,3 & - & - & - & - & 3 & 100,0 \\
\hline Nordeste & 3 & 16,7 & 5 & 27,8 & 4 & 22,2 & 6 & 33,3 & 18 & 100,0 \\
\hline Sudeste & 2 & 10,5 & 3 & 15,8 & 6 & 31,6 & 8 & 42,1 & 19 & 100,0 \\
\hline Sul & 3 & 60,0 & 1 & 20,0 & - & - & 1 & 20,0 & 5 & 100,0 \\
\hline Total & 10 & 22,2 & 10 & 22,2 & 10 & 22,2 & 15 & 33,3 & 45 & 100,0 \\
\hline
\end{tabular}

Fonte: Câmara dos Deputados (Repertório Biográfico) e Senado Federal (Dados Biográficos)

A circulação de membros do Congresso Nacional entre outros cargos eletivos e/ou públicos encontra-se diretamente relacionada à existência de uma série de dificuldades que obstam o desenvolvimento contínuo de muitas carreiras políticas no interior do Parlamento. Entretanto, aqueles que conseguiram superá-las, controlando os recursos de poder disponíveis em ambas as Casas, foram justamente os que ascenderam à condição de elite. Como se 
verifica nas Tabelas $8 \mathrm{~A}$ e $8 \mathrm{~B}$, a elite parlamentar do pós-Constituinte era composta principalmente por congressistas cuja experiência profissional no Congresso era bem mais longa e contínua do que a dos demais membros do Legislativo (Tabela $8 \mathrm{C}$, ver Anexo). Além disso, a taxa de renovação dos parlamentares da elite ao longo do período considerado (em média, 26\%) foi também muito inferior àquela observada no Congresso Nacional (em média, 51\%). ${ }^{12}$. Experiência e continuidade na vida legislativa foram, portanto, fatores importantes, embora não indispensáveis, para a formação de um membro da elite do Congresso.

As Tabelas 8A e 8B apontam, também, não só para distinções entre os membros da elite com relação ao número de mandatos assumidos em cada uma das Casas do Congresso, ${ }^{13}$ como revelam ainda que, houve durante o período em foco, um crescimento significativo, na elite, de parlamentares mais experientes no Congresso Nacional. De fato, se, na $48^{\mathrm{a}}$ e $49^{\text {a }}$ legislaturas, a maior incidência de membros da elite encontrava-se entre aqueles que exerciam seu segundo mandato $(42,2 \%)$, nas $50^{\mathrm{a}}, 51^{\mathrm{a}}$ e $52^{\mathrm{a}}$ legislaturas esse percentual concentrou-se naqueles que já haviam exercido o quarto ou mais mandatos $(33,3 \%)$.

A curta vivência parlamentar no âmbito federal não foi impedimento à participação na elite de parcela significativa dos representantes do Sudeste (30\%) na $48^{\mathrm{a}}$ e $49^{\mathrm{a}}$ legislaturas, e para os congressistas do Sul nas legislaturas seguintes (60\%). Para os congressistas nordestinos, a aquisição de maior experiência no Congresso Nacional parece ter sido condição necessária ao seu ingresso nesse restrito grupo. Tanto nas duas primeiras legislaturas enfocadas, quanto nas demais, acima de $55 \%$ deles se encontravam entre três ou mais mandatos.

À maior longevidade no Parlamento entre os membros da elite, comparativamente aos congressistas como um todo, não 
correspondeu uma rotatividade partidária mais intensa. Pelo contrário, em cotejo com o Congresso Nacional (Tabela 9C, ver Anexo), observa-se, no seio da elite, maiores índices de fidelidade partidária ao longo da carreira parlamentar desses políticos. As Tabelas 9A e 9B revelam que, dos membros da elite da $48^{\mathrm{a}}$ e $49^{\mathrm{a}}$ legislaturas, $42,5 \%$ nunca haviam trocado de partido e entre os da $50^{\mathrm{a}}, 51^{\mathrm{a}}$ e $52^{\mathrm{a}}$ Legislaturas, $35,6 \%$ procederam da mesma forma. No Congresso Nacional, a rotatividade partidária nos dois períodos considerados foi empreendida, em média, por $70,7 \%$ de seus membros.

As Tabelas 9A e 9B informam, ainda, que houve variações entre os períodos considerados no que se refere à rotatividade partidária entre os membros da elite. Os representantes nordestinos que, de 1989 a 1994, apresentaram maior percentual de rotatividade partidária (100\% tinham mudado de partido pelo menos uma vez), passam a constituir, nas legislaturas posteriores, grupo com maior índice de fidelidade partidária (44,4\%). Os congressistas do Sudeste, cuja composição na $48^{\mathrm{a}}$ e $49^{\mathrm{a}}$ revelava que a metade nunca havia trocado de partido, exibem uma redução no percentual de fidelidade partidária entre seus membros $(31,6 \%)$. Essa queda encontra-se certamente relacionada ao aumento do número de parlamentares desse grupo da elite com longa vida partidária. Como se observa na Tabela 8B, 73,7\% desses já se encontravam, entre 1995 e 2004, em seu terceiro ou maior número de mandatos.

A mudança mais significativa em termos da composição regional dos membros da elite no quesito rotatividade partidária ocorreu, todavia, entre os parlamentares do Sul. Se, entre 1989 e 1994, esse grupo foi composto por parlamentares que majoritariam ente eram fiéis aos seus partidos, nas legislaturas seguintes, entre os membros da elite do Sul, apenas $20 \%$ deles se apresentavam na mesma condição. Essa mudança parece estar diretamente relacionada à grande redução dos parlamentares gaúchos no seio da 


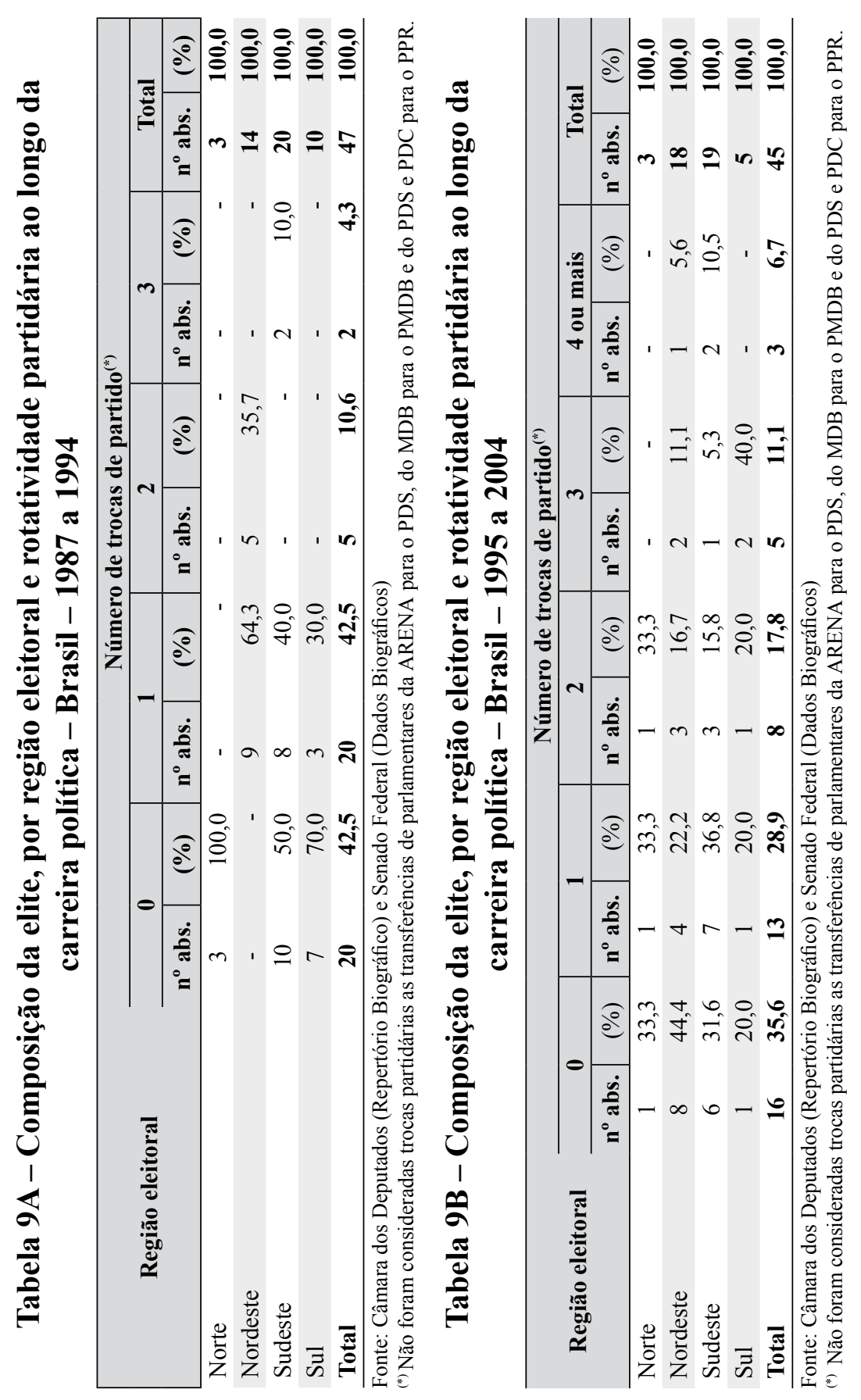


elite durante a $50^{\mathrm{a}}, 51^{\mathrm{a}}$ e $52^{\mathrm{a}}$ legislaturas. Nas entrevistas realizadas com parlamentares sulistas, sobretudo os gaúchos, a permanência nas agremiações partidárias de origem foi enfaticamente ressaltada como uma necessidade para a manutenção de suas carreiras parlamentares. Em verdade, tais entrevistados foram unânimes em apontar a intensa rotatividade partidária existente no Congresso Nacional como prática extremamente maculadora da imagem pública dos representantes políticos, sendo amplamente rejeitada pelos eleitores do Sul do País. Embora essa perspectiva esteja diretamente relacionada à própria concepção que os parlamentares do Sul elaboram sobre si mesmos - e que reproduz muitas das construções míticas presentes no imaginário dos naturais dessa região ${ }^{14}$ - deve-se salientar que o "troca-troca" partidário vigente no Congresso Nacional não é avaliado similarmente em todo o Brasil. Não obstante, há, no âmbito da elite, discurso ${ }^{15}$ comum de repúdio à excessiva permissividade do sistema eleitoral diante da intensa rotatividade partidária dos membros do Parlamento, mesmo entre aqueles cuja trajetória política foi marcada por certa infidelidade às agremiações de origem, ou cujo eleitorado não apresenta tamanha rejeição a essa prática.

O último indicador que merece destaque nesta caracterização da elite parlamentar do pós-Constituinte refere-se à preponderância, em seu interior, dos congressistas filiados aos grandes partidos, mais claramente identificados com as orientações de centro e de direita (Tabelas 10A e 10B). Tal como se verificou no Congresso (Tabela 2C e 3C), o PMDB e o PFL foram os grandes partidos representados na elite. Na realidade - e como era de se esperar, considerando os recursos de poder das grandes agremiações no Parlamento -, a participação conjunta dos congressistas desses dois partidos na elite, em média 57,2\% durante o período focalizado, superou a sua alocação de cadeiras no Congresso Nacional, em média 41\%. Assiste-se, contudo, ao longo desses anos, no âmbito da elite, à sua diversificação em termos partidários e ao crescimento da participação 
de membros tanto da esquerda quanto da direita. Interessante observar que a expansão da esquerda na elite deu-se em proporção bem superior (44\%) à verificada no Congresso (25,3\%). Com relação ao crescimento dos membros da direita na elite $(28,2 \%)$, ele não se reproduziu no Congresso Nacional, tendo ocorrido, inclusive, nos períodos considerados, uma redução em 15,6\% em seu número.

Afora o crescimento contínuo da bancada do PT nos últimos quinze anos, é certo que a existência de uma orientação políticoideológica mais definida nesse partido, assim como nos pequenos partidos de esquerda - aliada à forte identidade e ao compromisso estabelecidos entre tais parlamentares e suas legendas, além da baixa rotatividade partidária existente nos seus quadros - tem muito a informar sobre a significativa participação dos representantes da esquerda na elite parlamentar brasileira. No que se refere à expansão da direita e à diversidade de partidos que compuseram a elite, pode-se argumentar que a coligação vitoriosa na era FHC entre o PSDB e o PFL, que contou com o apoio da maioria dos pequenos partidos de direita, assim como o esvaziamento crescente do PMDB, como partido majoritário no Congresso Nacional, são elementos explicativos importantes para tal expansão.

Em termos da distribuição regional dos membros da elite entre os principais partidos, nota-se que, no interior desse grupo, os parlamentares do PFL, PSDB, PDT, PT eram majoritariamente representantes de seus principais redutos eleitorais. Isso significa que os membros do PFL, na elite, eram predominantemente congressistas nordestinos, enquanto os parlamentares do PSDB, PDT, PTB e PT representavam, em primazia, o Sudeste. No que alude aos congressistas do PMDB, reafirma-se, no seio da elite, a sua condição de partido nacional. Entretanto, a despeito da variedade regional dos parlamentares do PMDB, verifica-se, na elite, um significativo crescimento dos representantes nordestinos nessa agremiação. É possível afirmar que tal configuração esteja relacionada ao percentual considerável de senadores nordestinos 
do PMDB na elite, correspondente à sua respectiva supremacia no Senado.

\section{Tabela 10A - Composição da elite, por partido e região eleitoral Brasil - 1987 a 1995}

\begin{tabular}{|c|c|c|c|c|c|c|c|c|c|c|}
\hline \multirow{3}{*}{ Partido } & \multicolumn{10}{|c|}{ Região eleitoral } \\
\hline & \multicolumn{2}{|c|}{ Norte } & \multicolumn{2}{|c|}{ Nordeste } & \multicolumn{2}{|c|}{ Sudeste } & \multicolumn{2}{|c|}{ Sul } & \multicolumn{2}{|c|}{ Total } \\
\hline & $\begin{array}{c}\mathrm{n}^{\mathrm{o}} \\
\mathrm{abs} .\end{array}$ & $(\%)$ & $\begin{array}{c}\mathrm{n}^{\mathrm{o}} \\
\mathrm{abs} .\end{array}$ & $(\%)$ & $\begin{array}{c}\mathrm{N}^{\mathrm{o}} \\
\mathrm{abs} .\end{array}$ & $(\%)$ & $\begin{array}{c}\mathrm{n}^{\mathrm{o}} \\
\mathrm{abs} .\end{array}$ & $(\%)$ & $\begin{array}{c}n^{0} \\
\text { abs. }\end{array}$ & $(\%)$ \\
\hline PMDB & 2 & 7,7 & 7 & 26,2 & 8 & 30,8 & 9 & 34,6 & 26 & 100,0 \\
\hline PFL & - & - & 6 & 66,7 & 2 & 22,2 & 1 & 11,1 & 9 & 100,0 \\
\hline PDT & - & - & 1 & 25,0 & 3 & 75,0 & - & - & 4 & 100,0 \\
\hline PT & - & - & - & - & 3 & 100,0 & - & - & 3 & 100,0 \\
\hline PDS & 1 & 33,3 & - & - & 2 & 66,7 & - & - & 3 & 100,0 \\
\hline PSDB & - & - & - & - & 2 & 100,0 & - & - & 2 & 100,0 \\
\hline Total & 3 & 6,4 & 14 & 29,8 & 20 & 42,5 & 10 & 21,3 & 47 & 100,0 \\
\hline
\end{tabular}

Fonte: Câmara dos Deputados (Repertório Biográfico) e Senado Federal (Dados Biográficos).

\section{Tabela 10B - Composição da elite, por partido e região eleitoral - Brasil - 1995 a 2004}

\begin{tabular}{|c|c|c|c|c|c|c|c|c|c|c|}
\hline \multirow{3}{*}{ Partido } & \multicolumn{10}{|c|}{ Região eleitoral } \\
\hline & \multicolumn{2}{|c|}{ Norte } & \multicolumn{2}{|c|}{ Nordeste } & \multicolumn{2}{|c|}{ Sudeste } & \multicolumn{2}{|c|}{ Sul } & \multicolumn{2}{|c|}{ Total } \\
\hline & $\begin{array}{c}\mathrm{n}^{\mathrm{o}} \\
\mathrm{abs} .\end{array}$ & $(\%)$ & $\begin{array}{c}\mathrm{n}^{\mathrm{o}} \\
\text { abs. }\end{array}$ & $(\%)$ & $\begin{array}{c}\mathrm{N}^{\mathrm{o}} \\
\mathrm{abs} .\end{array}$ & $(\%)$ & $\begin{array}{c}\mathrm{n}^{\mathrm{o}} \\
\mathrm{abs} .\end{array}$ & $(\%)$ & $\begin{array}{c}\mathbf{n}^{\mathbf{o}} \\
\text { abs. }\end{array}$ & $(\%)$ \\
\hline PMDB & 1 & 11,1 & 5 & 55,5 & 2 & 22,2 & 1 & 11,1 & 9 & 100,0 \\
\hline PFL & - & - & 7 & 77.8 & 1 & 11,1 & 1 & 11,1 & 9 & 100,0 \\
\hline PSDB & 1 & 12,5 & 1 & 12,5 & 4 & 50,0 & 2 & 25,0 & 8 & 100,0 \\
\hline PT & - & - & 2 & 33,3 & 4 & 66,7 & - & - & 6 & 100,0 \\
\hline PPB & - & - & 1 & 33,3 & 1 & 33,3 & 1 & 33,3 & 3 & 100,0 \\
\hline PDT & 1 & 50,0 & - & - & 1 & 50,0 & - & - & 2 & 100,0 \\
\hline PTB & - & - & - & - & 2 & 100,0 & - & - & 2 & 100,0 \\
\hline PSB & - & - & 1 & 50,0 & 1 & 50,0 & - & - & 2 & 100,0 \\
\hline PL & - & - & - & - & 1 & 100,0 & - & - & 1 & 100,0 \\
\hline PP & - & - & - & - & 1 & 100,0 & - & - & 1 & 100,0 \\
\hline PPS & - & - & 1 & 100.0 & - & - & - & - & 1 & 100,0 \\
\hline PC do B & - & - & - & - & 1 & 100,0 & - & - & 1 & 100,0 \\
\hline Total & 3 & 6,7 & 18 & 40,0 & 19 & 42,2 & 5 & 11,1 & 45 & 100,0 \\
\hline
\end{tabular}

Fonte: Câmara dos Deputados (Repertório Biográfico) e Senado Federal (Dados Biográficos). 


\section{Conclusão}

Pode-se, enfim, traçar sumariamente o perfil da elite parlamentar brasileira do pós-Constituinte enquanto um grupo restrito, no qual se reproduziu, de forma semelhante ao que se configurava no Congresso Nacional, a supremacia de parlamentares naturais do Nordeste e do Sudeste do País. De maneira similar, embora em maiores proporções do que no Congresso como um todo, observa-se, na composição da elite, a prevalência dos grandes partidos de contorno ideológico conservador e o predomínio de congressistas detentores de nível superior, com ampla superioridade numérica dos bacharéis em Direito. A ocupação de cargos do alto escalão da burocracia do Estado fez igualmente parte da carreira política desses congressistas, ainda que de forma bem mais intensa do que aquela observada entre os demais parlamentares. A nãolinearidade hierárquica de suas carreiras profissionais também se revela uma característica comum em comparação com os outros membros do Congresso, apesar de, na elite, a conquista de cargos eletivos tidos como superiores ter sido mais incidente.

Em contraste com o Congresso Nacional, houve, na elite, maior participação de congressistas pertencentes aos partidos de esquerda e de direita, além da presença mais significativa de representantes do Sudeste e das capitais dos Estados. Ressalte-se, ainda, que as trajetórias políticas dos membros da elite distinguiamse por menores índices de rotatividade partidária, pela experiência de vida parlamentar no âmbito nacional e pela ampla conquista de cargos-chave no Legislativo.

Internamente à elite, surgiram certas distinções quanto ao perfil e à trajetória política de seus membros. No que diz respeito ao aspecto da naturalidade, entre os parlamentares nordestinos da elite, verificou-se a preponderância daqueles oriundos do interior dos Estados, enquanto que entre os nortistas e os do Sudeste, a primazia 
era dos metropolitanos. Entre os nordestinos registrou-se, ainda, movimento migracional mais intenso, principalmente em direção ao Sudeste do País. Em relação ao grau de instrução e às profissões mais freqüentes no meio dos parlamentares da elite, percebeu-se, entre os membros do Sudeste, uma maior diversidade dos níveis de educação formal e de profissões reveladas.

Quanto às suas trajetórias políticas, tem-se que, na ocupação de cargos públicos, os representantes do Sudeste foram os que mais conquistaram postos considerados "top de linha" na administração do Estado, ao passo que os nordestinos, além de terem detido colocação respeitável relativamente à conquista de cargos importantes nas administrações estaduais e municipais, assumiram prevalência na ocupação de postos gravitantes em torno dos chefes do Executivo em seus três níveis.

Na ocupação de cargos eletivos, para além da não-linearidade observada entre a grande maioria dos membros da elite, verificase, contudo, que os representantes do Nordeste foram os que mais ocuparam cargos de deputado estadual e governador, os membros do Sudeste foram os que mais exerceram a atividade de vereança e, finalmente, entre os parlamentares da elite do Sul, observou-se grande incidência de ex-prefeitos e governadores.

Foram, ainda, os nordestinos aqueles que mais investiram na construção de suas carreiras políticas dentro do Parlamento, tendo ocupado grande número de cargos-chave na estrutura organizacional do Congresso Nacional, com destaque para a conquista dos postos que compõem as mesas diretoras de ambas as Casas e as autorias de projetos relevantes. Já os representantes do Sudeste na elite destacaram-se pela preponderância na ocupação das lideranças partidárias, presidências de comissões e relatorias de projetos. De modo semelhante, a trajetória política trilhada no interior do Parlamento pelos congressistas do Sul concentrou-se mais na 
ocupação das presidências de comissões e relatorias de projetoschave para a agenda do Legislativo.

A experiência de vida parlamentar revelou-se, proporcionalmente, mais longa entre os representantes nordestinos da elite, do que no meio dos congressistas do Sudeste e do Sul, que reuniram o maior número de calouros. Eram, porém, nordestinos, os membros da elite que compunham a maior parte da bancada dos dois principais partidos do Congresso Nacional, enquanto a supremacia dos parlamentares do Sudeste se concentrava nas demais agremiações.

Os dados acima apontam para continuidades e descontinuidades entre o perfil e a trajetória política dos membros da elite do Congresso Nacional do pós-Constituinte e o tipo padrão de parlamentar brasileiro predominante durante esses anos, e, além disso, revelam diferenças de atuação e caracterização entre os próprios membros da elite.

Longe de pretender esgotar o tema, a reflexão aqui desenvolvida intenta abrir novos caminhos para o entendimento da vida política brasileira. Procurou-se fornecer elementos analíticos que possam vir a fomentar o debate acerca da importância da investigação da dimensão sociocultural e, associada a ela, dos papéis desempenhados pelas elites parlamentares no entendimento do sistema político brasileiro. Dimensões dessa ordem não têm sido muitas vezes consideradas analiticamente relevantes para a compreensão das formas como se concebe e realiza a política no País. Entretanto, aí reside uma agenda renovada e imprescindível para a construção de novas abordagens na seara dos estudos afeitos à Sociologia Política do Brasil. 


\section{Notas}

1 Foi analisada a trajetória de vida e política de 47 parlamentares que fizeram parte da elite do Congresso Nacional durante os anos enfocados. Entre esses, quinze foram entrevistados: Fernando Henrique Cardoso, Marco Maciel, José Sarney, Inocêncio de Oliveira, José Genoíno, Francisco Dornelles, Delfim Neto, Pedro Simon, Miro Teixeira, Nelson Jobim, Bernardo Cabral, Paes de Andrade, Mauro Benevides, Prisco Viana e Odacir Klein.

2 A parcialidade dos dados que serão apresentados neste artigo deve-se ao fato de que ainda se encontram em fase final de análise as informações relativas à produção legislativa dos parlamentares da elite do Congresso Nacional, entre os anos de 1995 a 2004, e a conclusão das entrevistas realizadas com membros da elite parlamentar do período.

3 Está-se próximo à concepção de "carisma" em Weber, a qual remete a "qualidades excepcionais" reconhecidas em um líder, cuja autoridade se obedece somente enquanto lhe forem atribuídos "dotes sobrenaturais" (Weber, 1974, Tomo II, p. 712).

4 Em verdade, no universo amostral da pesquisa e de acordo com os critérios de seleção adotados, não houve o recrutamento de nenhum representante do Centro-Oeste da elite parlamentar. Quanto aos representantes do Norte selecionados, esses não se encontravam em número suficiente para garantir a construção de um tipo ideal de parlamentar da elite do Congresso Nacional dessa região. Cabe ressaltar, contudo, que as informações obtidas na pesquisa do perfil, trajetória política e mesmo aquelas referentes à entrevista com representante nortista da elite serão utilizadas, como não poderia deixar de ser, na análise geral da elite parlamentar do Congresso Nacional. Deve-se informar, ainda, que foi considerada a Região Nordeste, e não a Região Norte do País, como a região de representação do senador José Sarney, membro da elite parlamentar nas $49^{\mathrm{a}}, 50^{\mathrm{a}}, 51^{\mathrm{a}}$ e $52^{\mathrm{a}}$ legislaturas. Isso porque, a despeito de o parlamentar ter sido eleito senador pelo Estado do Amapá nas últimas eleições, o ex-presidente construiu praticamente toda a sua carreira política no Estado do Maranhão e tanto a sua trajetória pessoal quanto política aproximam-no claramente dos 
representantes nordestinos. Esclareça-se, ademais, o enquadramento do senador - e posteriormente deputado federal - Roberto Campos como representante da Região Sudeste. Com efeito, durante a $48^{\text {a }}$ legislatura, o parlamentar Roberto Campos era Senador pelo Estado do Mato Grosso e na 49 $9^{\text {a }}$ legislatura, foi deputado pelo Estado do Rio de Janeiro. Tendo em vista que o período em foco recobre as duas legislaturas, porém integralmente somente a segunda, optamos por reconhecê-lo como legítimo representante do Sudeste. Acrescenta-se a isso, o fato de que o deputado Roberto Campos sempre disputou, desde 1991, cargos eletivos de representação no Estado do Rio de Janeiro.

5 Na bancada de posse das $50^{\mathrm{a}}, 51^{\mathrm{a}}$ e $52^{\mathrm{a}}$ legislaturas, o PSDB apresentava, respectivamente, $48,4 \%, 43 \%$ e $40,6 \%$ de seus parlamentares oriundos da Região Sudeste e o PT, 49\%, 44,1\% e 40,6\% (informação obtida na Secretaria da mesa da Câmara dos Deputados).

6 Embora alguns autores apontem como desnecessário o estabelecimento de percentuais para um universo menor do que 50, consideramos relevante a adoção desse procedimento, já que as amostras de 47 e 45 parlamentares são mais do que representativas do universo de congressistas que participaram da elite ao longo do período estudado: respectivamente, 123 parlamentares, entre 1987 e 1995, e 185 parlamentares, entre 1995 e 2004.

7 Entre 1987 e 1996, o PMDB deteve a maior bancada do Congresso Nacional. A partir de 1997, o partido apresentou a segunda ou terceira maior bancada na Câmara dos Deputados. No Senado, porém, mantevese em primeiro lugar, a despeito de sofrer contínuas reduções no número de seus representantes. Vide Tabela 2C e 3C, no Anexo. Para maiores detalhes a esse respeito, ver: Arruda (1990).

8 Segundo as informações obtidas nas entrevistas, $60 \%$ dos entrevistados admitiram ser o exercício parlamentar uma tradição na história de suas famílias.

9 Para maiores informações sobre o bacharelismo no Império, ver: Freyre, (1981, Cap. XI), Carvalho (1980), Adorno (1988).

10 Recursos esses diretamente relacionados à liberação e distribuição de verbas públicas, assim como à execução de ações coletivas e obras de impacto social. 
11 Trata-se, aqui, dos cargos de secretário de Estado e município e de assessor, chefe ou subchefe de gabinete de governador ou prefeito.

12 Dos que ocuparam tais postos no Sudeste, $57 \%$ fizeram-no antes do seu ingresso no Congresso Nacional.

13 Nas entrevistas realizadas com parlamantares da elite foi lhes questionado se eles percebiam diferenças entre congressistas de origens regionais distintas no exercício da atividade política. Todos foram unânimes em apontar que elas, de fato, existem. Mais do que reafirmarem identidades regionais, essas manifestações dos membros da elite demonstram como realidades e práticas distintas fundam e se alimentam de certas construções míticas que, ao serem constantemente ressignificadas e incorporadas por quem as vivencia, recebem estímulos sucessivos para a sua permanência. Além disso, sendo a construção da identidade social de um grupo ou de uma coletividade um processo de auto-representação, reconhecimento e diferenciação, este se consolida no cotejo com outras práticas simbólicas, assentadas em representações similares, complementares, ou mesmo antagônicas às suas. Estabelecese, assim, o conflito entre o mesmo e o diverso, onde cada um percebe a si próprio na comparação com os demais. Para maiores detalhes acerca das representações simbólicas entre os membros da elite parlamentar, ver: Messenberg (2002, p. 118-131).

14 De acordo com o Departamento Intersindical de Assessoria Parlamentar (DIAP), as taxas de renovação do Congresso Nacional nas eleições de 1990, 1994, 1998 e 2002 foram, respectivamente, de 62\%, $54 \%, 43 \%$ e $46 \%$.

15 Cabe lembrar que foram considerados somente os mandatos exercidos em uma das Casas do Congresso Nacional para cada parlamentar da elite.

16 Dentre as constelações míticas mais insistentemente reproduzidas entre os representantes sulistas da elite, em particular os gaúchos do interior, destaca-se o "culto à aldeia", local sacralizado de origem para o qual se deve sempre retornar em busca de revitalização do corpo e da alma (ver Messenberg, 2002, p. 126-127). 
17 O termo discurso está sendo aqui empregado de forma corrente, sem vinculação direta com o quadro epistemológico da "análise de discurso".

The Brazilian parliament elite (1989-2004)

Abstract: This article analyses the profile of the parliamentarians who constituted the Brazilian parliament elite between 1989 and 2004. It aims to identify the actors and their political practices and to understand how different socio-cultural shades interfere on the way of performing and thinking the politics in Brazil.

Keywords: parliament elite, socio-cultural dimension, national parliament.

\section{Referências}

ADORNO, Sérgio. Os aprendizes do poder: o bacharelismo liberal na política brasileira. Rio de Janeiro: Paz e Terra, 1988.

ALENCASTRO, Luiz F. de. O fardo dos bacharéis. Novos Estudos Cebrap, São Paulo, n. 19, p. 68-72, 1987.

AMARAL, Roberto (Coord.). FHC : os paulistas no poder. Rio de Janeiro: Casa Jorge Editorial, 1995.

ARRUDA, Maria A. do N. Mitologia da mineridade. São Paulo: Brasiliense. 1990.

BAAKLINI, Abdo I. O Congresso e o sistema político do Brasil. Rio de Janeiro: Paz e Terra, 1993.

BARTHES, Roland. Mitologias. Rio de Janeiro: Bertrand-Brasil, 1989.

BEZERRA, Marcos O. Em nome das "bases": política, favor e dependência pessoal. Rio de Janeiro: Relume Dumará, Núcleo de Antropologia da Política, 1999. 
BOTTOMORE, Tom. As elites e a sociedade. Rio de Janeiro: Zahar, 1965.

CARVALHO, José M. A construção da ordem: a elite política imperial. Rio de Janeiro: Campus, 1980.

DIAP. Quem foi quem na Constituinte. São Paulo: Cortez, Oboré, 1988.

FIGUEIREDO, A. C.; LIMONGI, F. O processo legislativo e a produção legal no Congresso pós-Constituinte. Novos Estudos Cebrap, São Paulo, n. 38, p. 24-37, 1994.

. Partidos políticos na Câmara dos Deputados: 1989-1994. Dados, v. 38, n. 3, p.497 a 525, 1995.

. Mudança constitucional, desempenho do Legislativo e Consolidação Institucional. Revista Brasileira de Ciências Sociais, v. 10, n. 10, p. 175-200, 1995.

. Congresso Nacional: organização, processo legislativo e produção legal. Cadernos de Pesquisa Cebrap, n. 5, 1996.

. O Congresso e as medidas provisórias: abdicação ou delegação? Novos Estudos Cebrap, n. 47, p 127-154, 1997.

FREYRE, Gilberto. Sobrados e mocambos: decadência do patriciado rural e desenvolvimento urbano. Rio de Janeiro: José Olympio, 1981.

GIRARDET, Raoul. Mitos e mitologias políticas. São Paulo: Companhia das Letras, 1987.

HOLANDA, Sérgio B. Raizes do Brasil. São Paulo: Companhia das Letras, 1995.

KINZO, Maria D’ Alva. Radiografia do quadro partidário brasileiro. São Paulo: Fundação Konrad-Adenauer-Stiftung, 1993.

LIMA, M. R. S.; CHEIBUB, Z. B. Instituições e valores: as dimensões da democracia na visão da elite brasileira. Revista Brasileira de Ciências Sociais, v. 11, n. 31, p. 83-110, 1996. 
LOVE, Joseph L. O regionalismo gaúcho e as origens da Revolução de 30. São Paulo: Perspectiva, 1975.

MESSENBERG, Débora. A elite parlamentar do pós-constituinte: atores e práticas. São Paulo: Brasiliense, 2002.

MICELI, Sérgio. Carne e osso da elite política brasileira pós-1930. In: BORIS, Fausto (Org.). História geral da civilização brasileira: tomo III - Brasil Republicano. Rio de Janeiro: Difel, 1983.

MIGUEL, Luis F. Em torno do conceito de mito político. Dados, v. 41, n. 3, p. 636-660, 1998.

NICOLAU, Jairo M. Multipartidarismo e democracia. Rio de Janeiro: Fundação Getúlio Vargas, 1996.

. As distorções na representação dos Estados na Câmara dos Deputados brasileira. Dados, v. 40, n. 3, p. 441-464, 1997.

. Sistemas eleitorais. Rio de Janeiro: Fundação Getúlio Vargas, 1999.

SANTOS, Fabiano. Patronagem e poder de agenda na política brasileira. Dados, v. 40, n. 3, p. 465-492, 1997.

SANTOS, Maria Helena de C. Governabilidade, governança e democracia: criação de capacidade governativa e relações Executivo-Legislativo no Brasil pós-Constituinte. Dados, v. 40, n. 3, p. 465-492, 1997.

TEIXEIRA, Carla C. A honra da política. Rio de Janeiro: Relume Dumará, Núcleo de Antropologia da Política, 1998.

WEBER, Max. Economia y sociedad. México: Fondo de Cultura Económica, 1974. Tomo I e II.

. Ciência e Política: duas vocações. São Paulo: Cultrix, 1993.

. Parlamento e governo na Alemanha reordenada: crítica política do funcionalismo e da natureza dos partidos. Petrópolis: Vozes, 1993. 


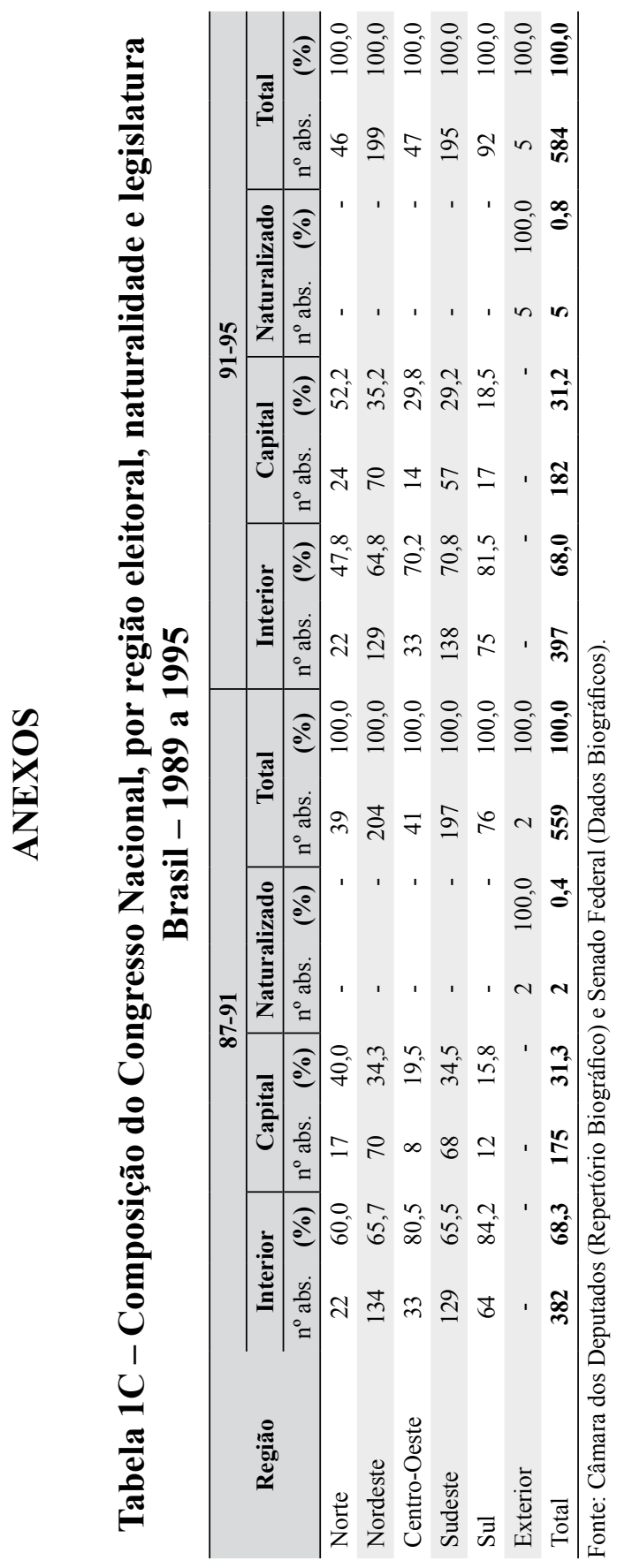



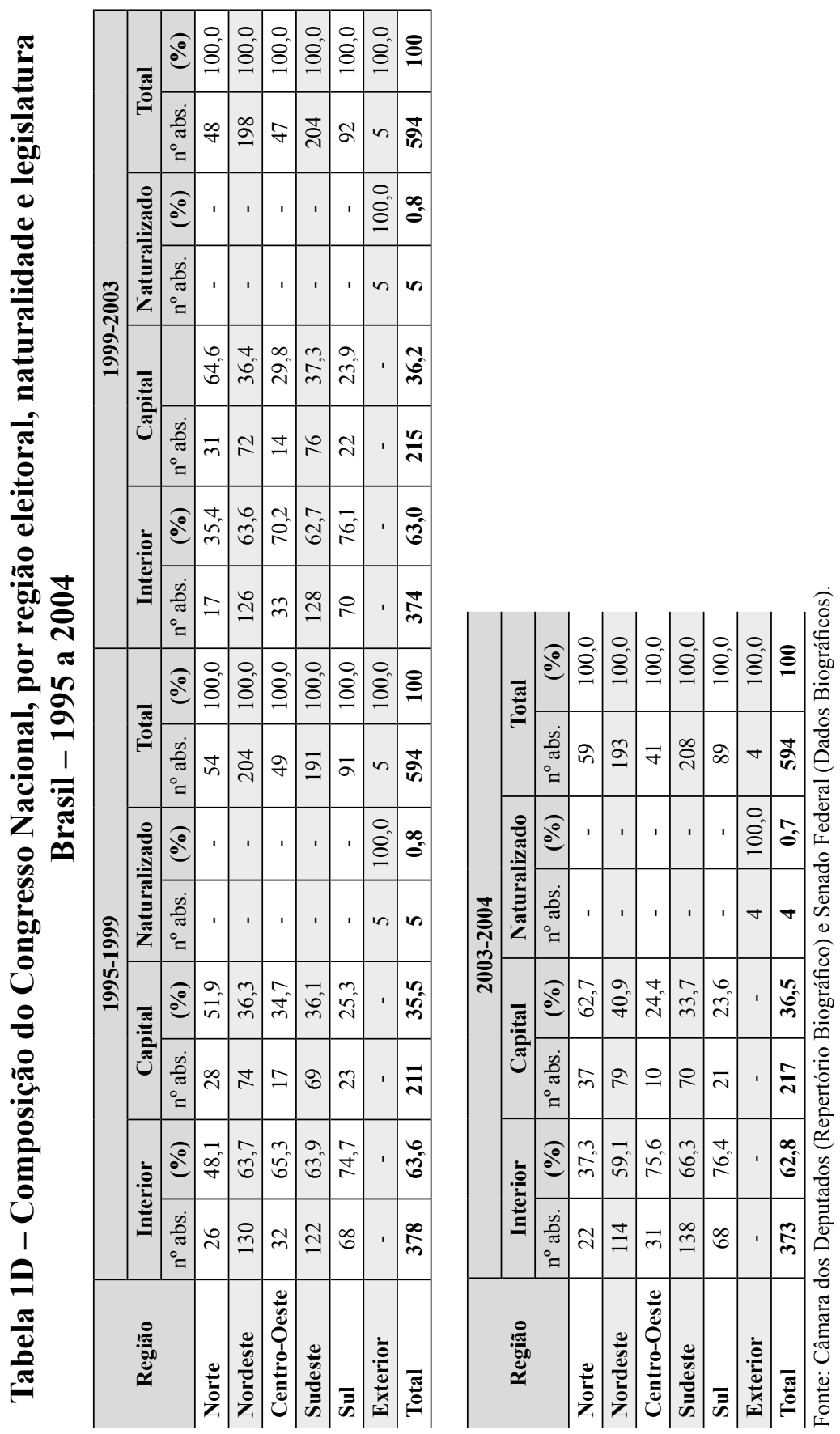
Tabela 2C - Composição partidária da Câmara dos Deputados - 1989-2004

\begin{tabular}{|c|c|c|c|c|c|c|c|c|c|c|}
\hline \multirow[b]{2}{*}{ Partido } & \multicolumn{2}{|c|}{1989} & \multicolumn{2}{|c|}{1990} & \multicolumn{2}{|c|}{1991} & \multicolumn{2}{|c|}{1992} & \multicolumn{2}{|c|}{1993} \\
\hline & $\begin{array}{c}\mathrm{n}^{\mathrm{o}} \\
\mathrm{abs} .\end{array}$ & $(\%)$ & $\begin{array}{l}\mathrm{n}^{\circ} \\
\text { abs. }\end{array}$ & $(\%)$ & $\begin{array}{c}\mathrm{n}^{\mathrm{o}} \\
\text { abs. }\end{array}$ & $(\%)$ & $\begin{array}{l}\mathrm{n}^{\mathrm{o}} \\
\mathrm{abs} .\end{array}$ & $(\%)$ & $\begin{array}{c}\mathrm{n}^{\mathrm{o}} \\
\mathrm{abs} .\end{array}$ & (\%) \\
\hline PMDB & 201 & 40,6 & 166 & 33,5 & 109 & 21,7 & 102 & 20,3 & 100 & 19,9 \\
\hline РТВ & 24 & 4,8 & 21 & 4,2 & 37 & 7,4 & 32 & 6,4 & 28 & 5,6 \\
\hline PDT & 27 & 5,5 & 31 & 6,3 & 46 & 9,1 & 43 & 8,5 & 44 & 8,7 \\
\hline $\mathrm{PT}$ & 16 & 3,2 & 16 & 3,2 & 35 & 7,0 & 35 & 7,0 & 35 & 7,0 \\
\hline PFL & 111 & 22,4 & 95 & 19,2 & 85 & 16,9 & 82 & 16,3 & 86 & 17,1 \\
\hline PL & 8 & 1,6 & 19 & 3,8 & 15 & 3,0 & 19 & 3,8 & 15 & 3,0 \\
\hline $\mathrm{PC}$ do $\mathrm{B}$ & 6 & 1,2 & 6 & 1,2 & 5 & 1,0 & 5 & 1,0 & 6 & 1,2 \\
\hline PSB & 6 & 1,2 & 7 & 1,4 & 10 & 2,0 & 11 & 2,2 & 9 & 1,8 \\
\hline PSDB & 42 & 8,5 & 53 & 10,7 & 38 & 7,6 & 41 & 8,2 & 37 & 7,4 \\
\hline PSC & 2 & 0,4 & 2 & 0,4 & 5 & 1,0 & 9 & 1,8 & 5 & 1,0 \\
\hline PMN & 1 & 0,2 & - & - & 1 & 0,2 & - & - & - & - \\
\hline PRONA & - & - & - & - & - & - & - & - & 1 & 0,2 \\
\hline PRP & - & - & 1 & 0,2 & - & - & - & - & - & - \\
\hline PPS & - & - & - & - & - & - & - & - & 3 & 0,6 \\
\hline PV & - & - & - & - & - & - & 1 & 0,2 & 1 & 0,2 \\
\hline PP & - & - & - & - & - & - & - & - & 32 & 6,4 \\
\hline PSTU & - & - & - & - & - & - & - & - & - & - \\
\hline PHS & - & - & - & - & - & - & - & - & - & - \\
\hline PSDC & - & - & - & - & - & - & - & - & - & - \\
\hline PTN & - & - & - & - & - & - & - & - & - & - \\
\hline PSL & - & - & - & - & - & - & - & - & - & - \\
\hline PPR & - & - & - & - & - & - & - & - & - & - \\
\hline PPB & - & - & 1 & 0,2 & - & - & - & - & - & - \\
\hline PSD & 1 & 0,2 & 1 & 0,2 & - & - & - & - & 5 & 1,0 \\
\hline PST & - & - & 1 & 0,2 & 2 & 0,4 & 8 & 1,6 & - & - \\
\hline PRN & - & - & 22 & 4,4 & 40 & 8,0 & 32 & 6,4 & 22 & 4,4 \\
\hline PDC & 13 & 2,6 & 14 & 2,8 & 22 & 4,4 & 19 & 3,8 & 16 & 3,2 \\
\hline PDS & 30 & 6,1 & 28 & 5,7 & 44 & 8,7 & 41 & 8,2 & 52 & 10,3 \\
\hline PTR & 1 & 0,2 & 1 & 0,2 & 2 & 0,4 & 13 & 2,6 & - & - \\
\hline PJ & 1 & 0,2 & - & - & - & - & - & - & - & - \\
\hline $\mathrm{PCN}$ & - & - & 1 & 0,2 & - & - & - & - & - & - \\
\hline PLP & - & - & 1 & 0,2 & - & - & - & - & - & - \\
\hline PRS & - & - & - & - & 4 & 0,8 & 3 & 0,6 & 3 & 0,6 \\
\hline PCB & 3 & 0,6 & 3 & 0,6 & 3 & 0,6 & 3 & 0,6 & - & - \\
\hline S/Partido & 2 & 0,4 & 5 & 1,0 & - & - & 4 & 0,8 & 2 & 0,4 \\
\hline Vago & - & - & - & - & - & - & - & - & 1 & 0,2 \\
\hline Total & 495 & 100,0 & 495 & 100,0 & 503 & 100,0 & 503 & 100,0 & 503 & 100,0 \\
\hline
\end{tabular}


Tabela 2C - Composição partidária da Câmara dos Deputados - 1989-2004

\begin{tabular}{|c|c|c|c|c|c|c|c|c|c|c|}
\hline \multirow[b]{2}{*}{ Partido } & \multicolumn{2}{|c|}{1995} & \multicolumn{2}{|c|}{1996} & \multicolumn{2}{|c|}{1997} & \multicolumn{2}{|c|}{1998} & \multicolumn{2}{|c|}{1999} \\
\hline & $\begin{array}{l}\mathrm{n}^{\mathrm{o}} \\
\text { abs. }\end{array}$ & (\%) & $\begin{array}{l}\mathrm{n}^{\mathrm{o}} \\
\text { abs. }\end{array}$ & $(\%)$ & $\begin{array}{c}\mathrm{n}^{\circ} \\
\text { abs. }\end{array}$ & $(\%)$ & $\begin{array}{l}\mathrm{n}^{\mathrm{o}} \\
\text { abs. }\end{array}$ & $(\%)$ & $\begin{array}{l}\mathrm{n}^{\mathrm{o}} \\
\mathrm{abs} \text {. }\end{array}$ & $(\%)$ \\
\hline PMDB & 108 & 21,1 & 101 & 19,7 & 97 & 18,9 & 87 & 17,0 & 86 & 16,8 \\
\hline РТВ & 31 & 6,0 & 28 & 5,5 & 26 & 5,1 & 25 & 4,9 & 30 & 5,8 \\
\hline PDT & 33 & 6,4 & 27 & 5,3 & 27 & 5,3 & 24 & 4,7 & 25 & 4,9 \\
\hline PT & 50 & 9,7 & 50 & 9,7 & 50 & 9,7 & 49 & 9,6 & 59 & 11,5 \\
\hline PFL & 88 & 17,2 & 99 & 19,3 & 99 & 19,3 & 110 & 21,4 & 106 & 20,7 \\
\hline PL & 14 & 2,7 & 8 & 1,6 & 8 & 1,6 & 10 & 1,9 & 12 & 2,3 \\
\hline $\mathrm{PC}$ do $\mathrm{B}$ & 10 & 1,9 & 10 & 1,9 & 10 & 1,9 & 9 & 1,8 & 7 & 1,4 \\
\hline PSB & 15 & 2,9 & 11 & 2,1 & 12 & 2,3 & 13 & 2,5 & 18 & 3,5 \\
\hline PSDB & 65 & 12,7 & 81 & 15,8 & 84 & 16,4 & 92 & 17,9 & 95 & 18,5 \\
\hline PSC & 2 & 0,4 & 1 & 0,2 & 1 & 0,2 & - & - & 2 & 0,4 \\
\hline PMN & 3 & 0,6 & 2 & 0,4 & 2 & 0,4 & 2 & 0,4 & 2 & 0,4 \\
\hline PRONA & - & - & - & - & - & - & 1 & 0,2 & 1 & 0,2 \\
\hline PRP & 1 & 0,2 & - & - & - & - & - & - & - & - \\
\hline PPS & 3 & 0,6 & 3 & 0,6 & 3 & 0,6 & 7 & 1,4 & 4 & 0,8 \\
\hline PV & 1 & 0,2 & 1 & 0,2 & 1 & 0,2 & 1 & 0,2 & 1 & 0,2 \\
\hline PP & 32 & 6,2 & - & - & - & - & - & - & - & - \\
\hline PSTU & - & - & - & - & - & - & 1 & 0,2 & - & - \\
\hline PHS & - & - & - & - & - & - & - & - & - & - \\
\hline PSDC & - & - & - & - & - & - & - & - & - & - \\
\hline PTN & - & - & - & - & - & - & - & - & - & - \\
\hline PSL & - & - & 1 & 0,2 & 1 & 0,2 & - & - & 1 & 0,2 \\
\hline PPR & 50 & 9,7 & - & - & - & - & - & - & - & - \\
\hline PPB & 3 & 0,6 & 85 & 16,6 & 87 & 17,0 & 78 & 15,2 & 60 & 11,7 \\
\hline PSD & 3 & 0,6 & 4 & 0,8 & 4 & 0,8 & 3 & 0,6 & 3 & 0,6 \\
\hline PST & - & - & 1 & 0,2 & 1 & 0,2 & 1 & 0,195 & 1 & 0,2 \\
\hline PRN & 1 & 0,2 & - & - & - & - & - & - & - & - \\
\hline PDC & - & - & - & - & - & - & - & - & - & - \\
\hline PDS & - & - & - & - & - & - & - & - & - & - \\
\hline PTR & - & - & - & - & - & - & - & - & - & - \\
\hline PJ & - & - & - & - & - & - & - & - & - & - \\
\hline $\mathrm{PCN}$ & - & - & - & - & - & - & - & - & - & - \\
\hline PLP & - & - & - & - & - & - & - & - & - & - \\
\hline PRS & - & - & - & - & - & - & - & - & - & - \\
\hline PCB & - & - & - & - & - & - & - & - & - & - \\
\hline S/Partido & - & - & - & - & - & - & - & - & - & - \\
\hline Vago & - & - & - & - & - & - & - & - & - & - \\
\hline Total & 513 & 100 & 513 & 100 & 513 & 100 & 513 & 100 & 513 & 100 \\
\hline
\end{tabular}


Tabela 2C - Composição partidária da Câmara dos Deputados - 1989-2004

\begin{tabular}{|c|c|c|c|c|c|c|c|c|c|c|}
\hline \multirow[b]{2}{*}{ Partido } & \multicolumn{2}{|c|}{2000} & \multicolumn{2}{|c|}{2001} & \multicolumn{2}{|c|}{2002} & \multicolumn{2}{|c|}{2003} & \multicolumn{2}{|c|}{2004} \\
\hline & $\begin{array}{c}\mathrm{n}^{\mathrm{o}} \\
\mathrm{abs} .\end{array}$ & $(\%)$ & $\begin{array}{l}\mathrm{n}^{\mathrm{o}} \\
\mathrm{abs} \text {. }\end{array}$ & (\%) & $\begin{array}{l}\mathrm{n}^{\mathrm{o}} \\
\mathrm{abs} \text {. }\end{array}$ & $(\%)$ & $\begin{array}{l}\mathrm{n}^{\mathrm{o}} \\
\text { abs. }\end{array}$ & $(\%)$ & $\begin{array}{l}\mathrm{n}^{\mathrm{o}} \\
\mathrm{abs} \text {. }\end{array}$ & $(\%)$ \\
\hline PMDB & 99 & 19,3 & 98 & 19,1 & 89 & 17,3 & 76 & 14,8 & 78 & 15,2 \\
\hline РТВ & 24 & 4,7 & 25 & 4,9 & 34 & 6,6 & 28 & 5,5 & 51 & 9,9 \\
\hline PDT & 22 & 4,3 & 18 & 3,5 & 15 & 2,9 & 20 & 3,9 & 14 & 2,7 \\
\hline PT & 59 & 11,5 & 59 & 11,5 & 61 & 11,9 & 91 & 17,7 & 91 & 17,7 \\
\hline PFL & 105 & 20,5 & 102 & 19,9 & 99 & 19,3 & 84 & 16,4 & 65 & 12,7 \\
\hline PL & 10 & 1,9 & 13 & 2,5 & 22 & 4,3 & 24 & 4,7 & 40 & 7,8 \\
\hline PC do B & 7 & 1,4 & 7 & 1,4 & 7 & 1,4 & 11 & 2,1 & 10 & 1,9 \\
\hline PSB & 14 & 2,7 & 15 & 2,9 & 16 & 3,1 & 22 & 4,3 & 16 & 3,1 \\
\hline PSDB & 98 & 19,1 & 101 & 19,7 & 92 & 17,9 & 70 & 13,6 & 54 & 10,5 \\
\hline PSC & - & - & - & - & - & - & 2 & 0,4 & 6 & 1,2 \\
\hline PMN & - & - & - & - & - & - & 1 & 0,2 & - & - \\
\hline PRONA & - & - & - & - & - & - & 6 & 1,2 & 2 & 0,4 \\
\hline PRP & - & - & - & - & - & - & - & - & - & - \\
\hline PPS & 11 & 2,1 & 12 & 2,3 & 13 & 2,5 & 15 & 2,9 & 23 & 4,5 \\
\hline PV & 1 & 0,2 & 1 & 0,2 & - & - & 5 & 1,0 & 7 & 1,4 \\
\hline PP & - & - & - & - & - & - & - & - & 52 & 10,1 \\
\hline PSTU & - & - & - & - & - & - & - & - & - & - \\
\hline PHS & 1 & 0,2 & 1 & 0,2 & 1 & 0,2 & - & - & - & - \\
\hline PSDC & - & - & - & - & 1 & 0,2 & 1 & 0,2 & - & - \\
\hline PTN & 2 & 0,4 & 2 & 0,4 & 2 & 0,4 & - & - & - & - \\
\hline PSL & 1 & 0,2 & 4 & 0,8 & 4 & 0,8 & 1 & 0,2 & 2 & 0,4 \\
\hline PPR & - & - & - & - & - & - & - & - & - & - \\
\hline PPB & 51 & 9,9 & 47 & 9,2 & 52 & 10,1 & 50 & 9,7 & 1 & 0,2 \\
\hline PSD & - & - & - & - & - & - & 4 & 0,8 & - & - \\
\hline PST & 7 & 1,4 & 7 & 1,4 & 4 & 0,8 & 2 & 0,4 & - & - \\
\hline PRN & - & - & - & - & - & - & - & - & - & - \\
\hline PDC & - & - & - & - & - & - & - & - & - & - \\
\hline PDS & - & - & - & - & - & - & - & - & - & - \\
\hline PTR & - & - & - & - & - & - & - & - & - & - \\
\hline PJ & - & - & - & - & - & - & - & - & - & - \\
\hline $\mathrm{PCN}$ & - & - & - & - & - & - & - & - & - & - \\
\hline PLP & - & - & - & - & - & - & - & - & - & - \\
\hline PRS & - & - & - & - & - & - & - & - & - & - \\
\hline PCB & - & - & - & - & - & - & - & - & - & - \\
\hline S/Partido & 1 & 0,2 & 1 & 0,2 & 1 & 0,2 & - & - & 1 & 0,2 \\
\hline Vago & - & - & - & - & - & - & - & - & - & - \\
\hline Total & 513 & 100 & 513 & 100 & 513 & 100 & 513 & 100 & 513 & 100 \\
\hline
\end{tabular}

Fonte: Secretaria geral da Mesa da Câmara dos Deputados 


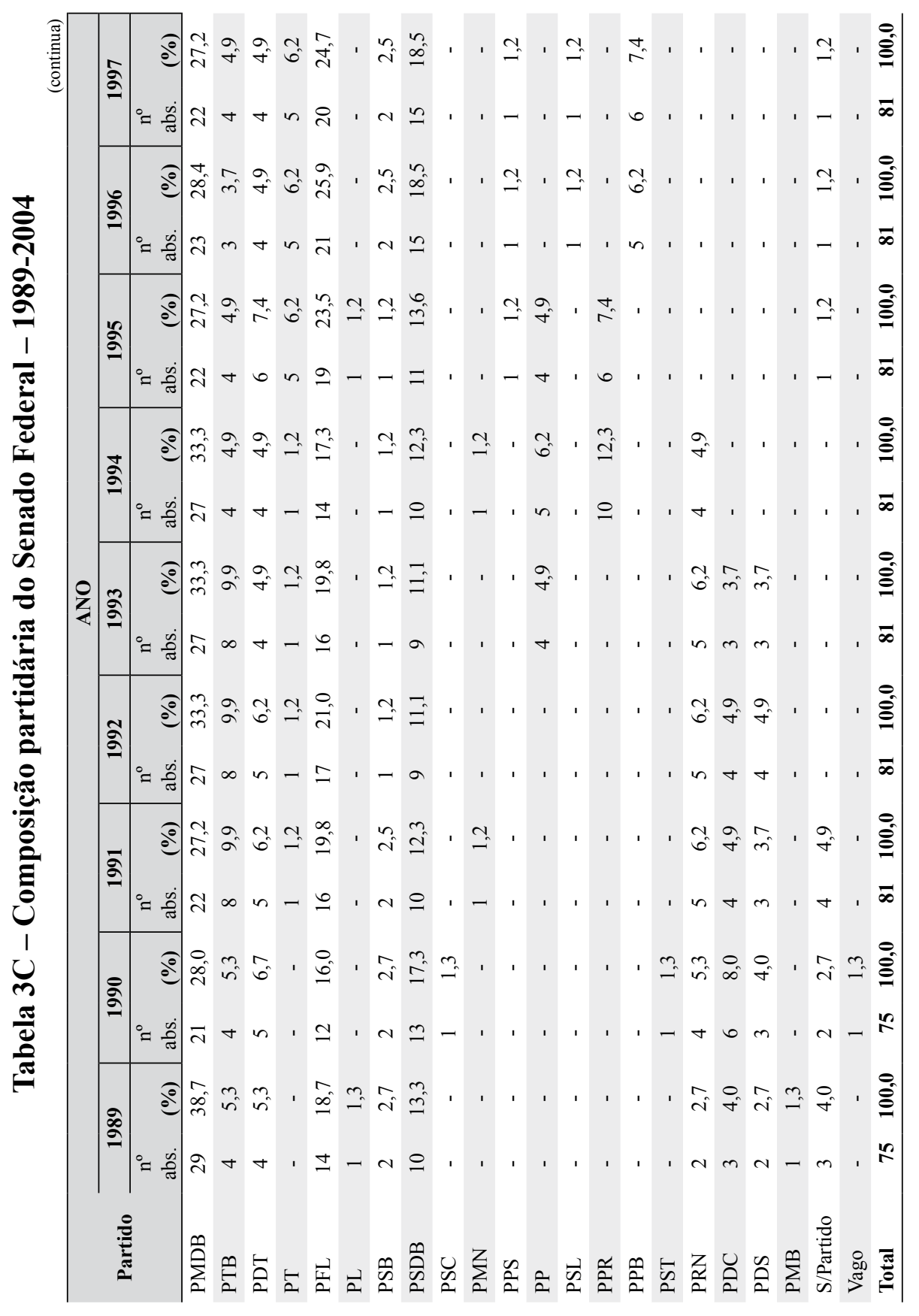




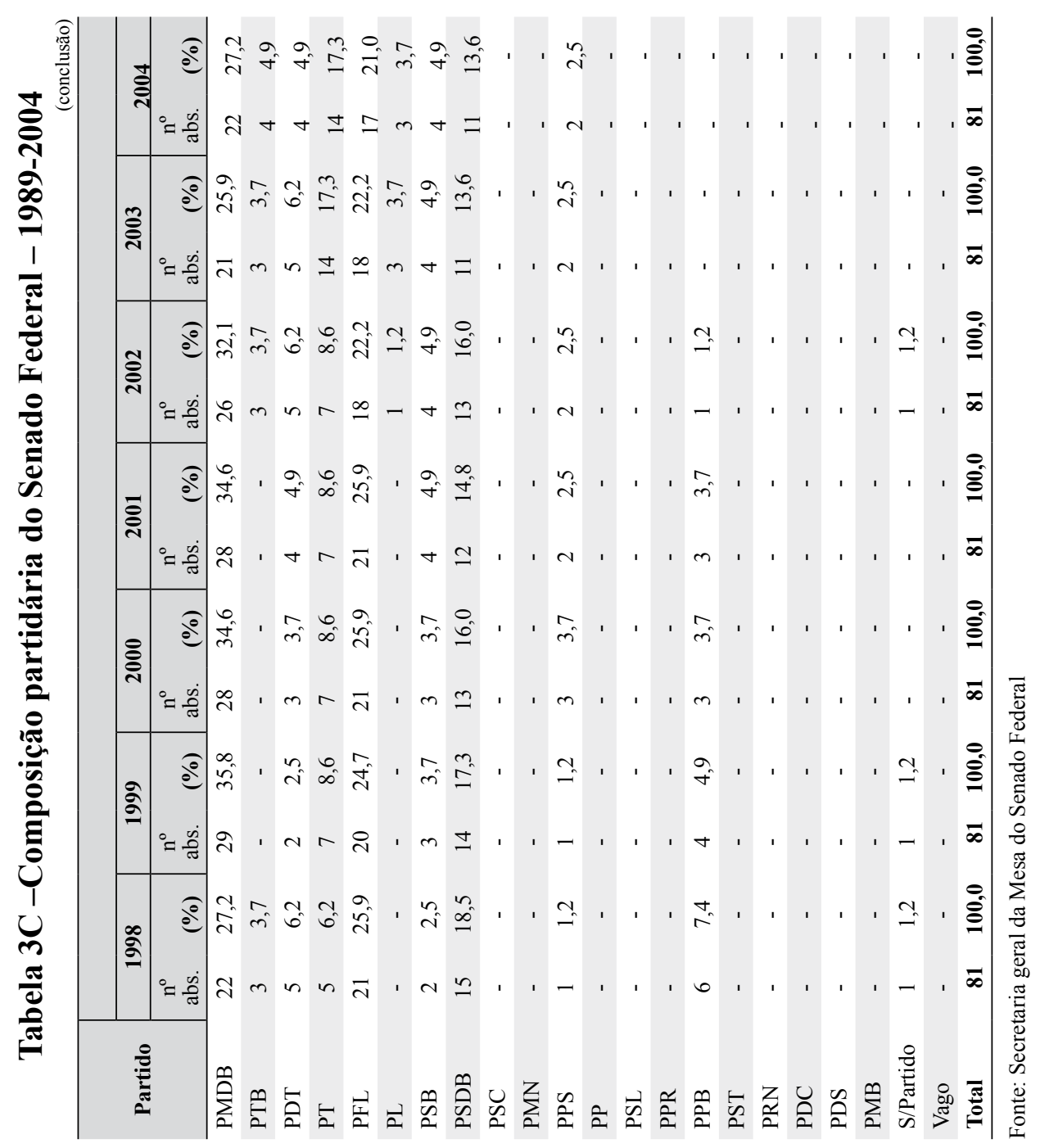




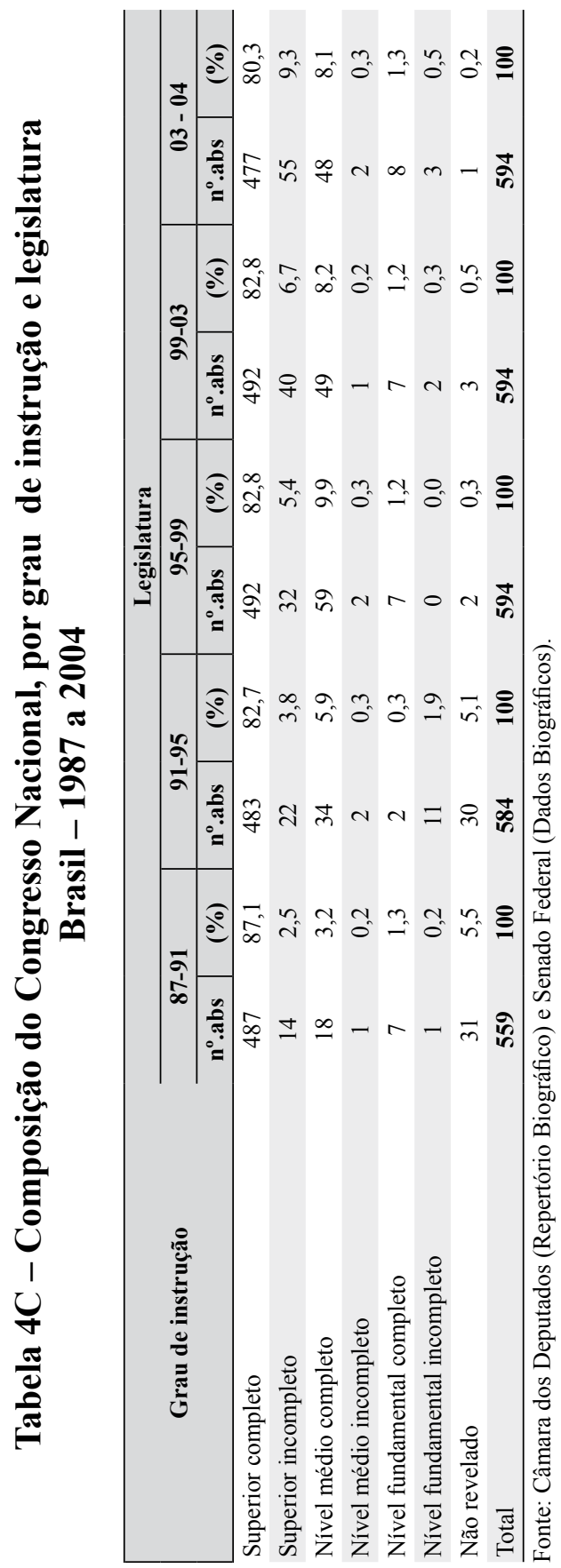




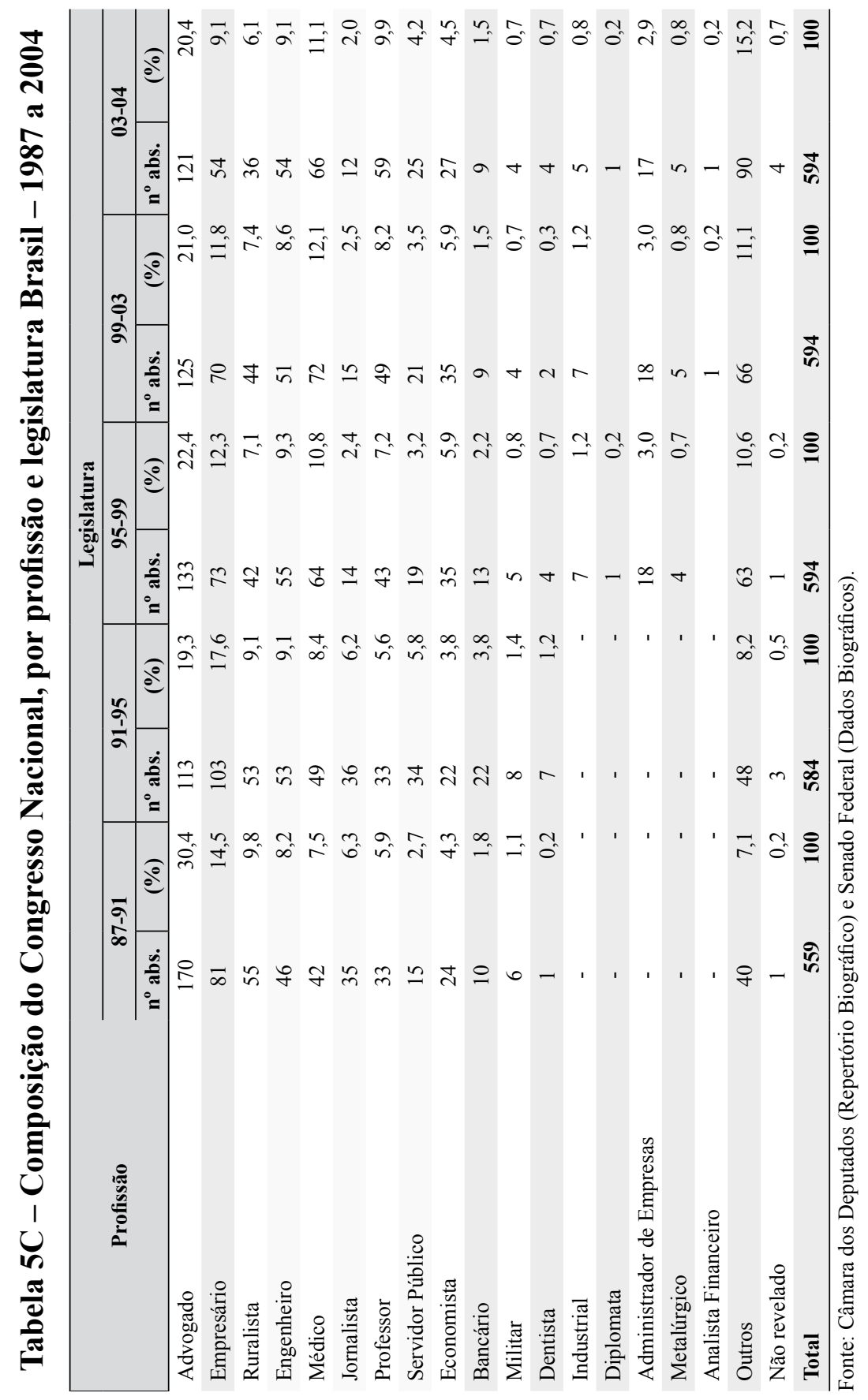




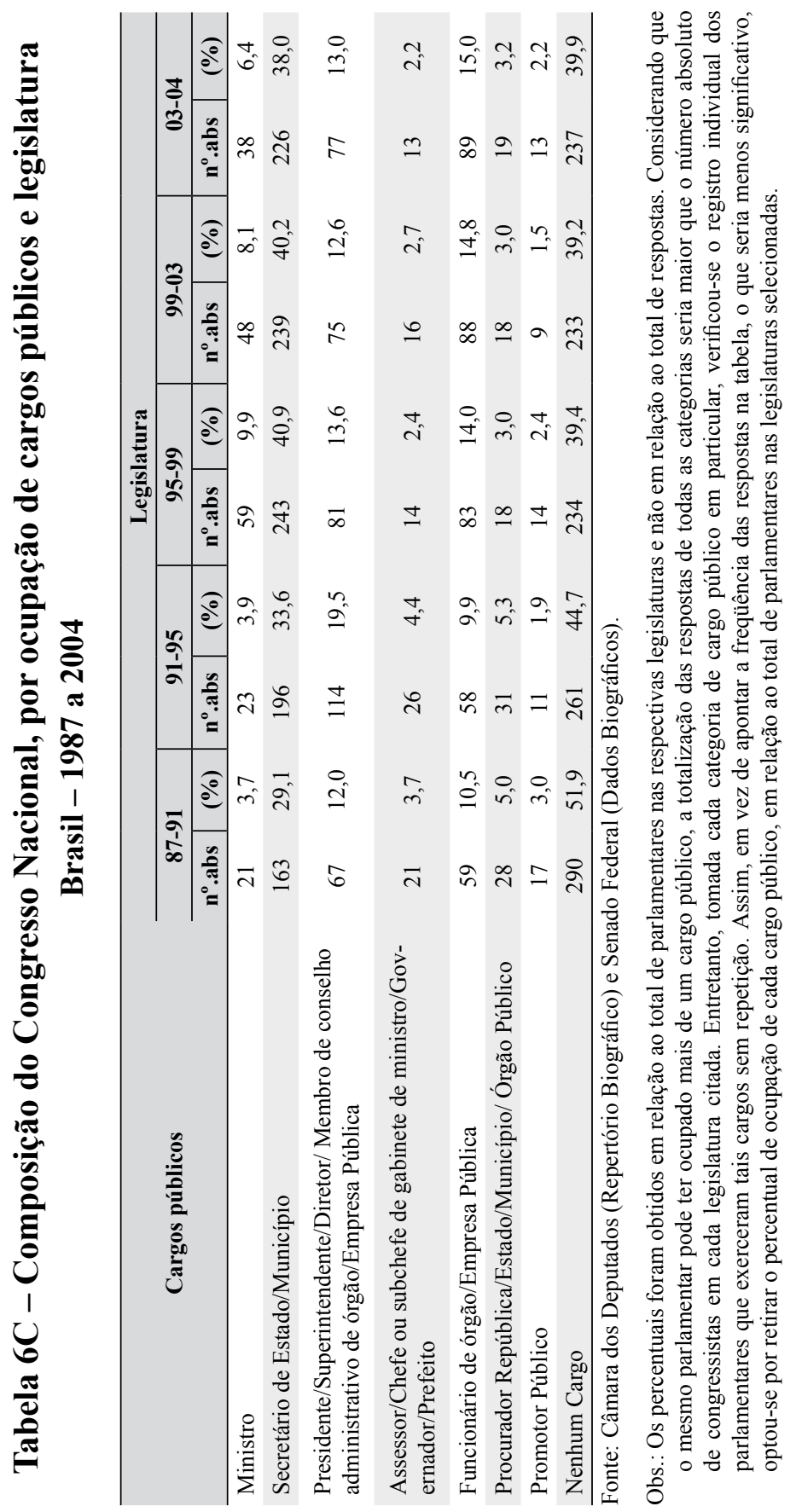




\section{Tabela 7C - Composição do Congresso Nacional, por ocupação de cargos eletivos e legislatura Brasil - 1987 a 2004}

\begin{tabular}{|c|c|c|c|c|c|c|c|c|c|c|}
\hline \multirow{3}{*}{ Cargos eletivos } & \multicolumn{10}{|c|}{ Legislatura } \\
\hline & \multicolumn{2}{|c|}{$87-91$} & \multicolumn{2}{|c|}{ 91-95 } & \multicolumn{2}{|c|}{ 95-99 } & \multicolumn{2}{|c|}{ 99-03 } & \multicolumn{2}{|c|}{$03-04$} \\
\hline & $\begin{array}{l}n^{\circ} \\
\text { abs. }\end{array}$ & $(\%)$ & $\begin{array}{l}\mathbf{n}^{0} \\
\text { abs. }\end{array}$ & $(\%)$ & $\begin{array}{l}\mathrm{n}^{0} \\
\text { abs. }\end{array}$ & $(\%)$ & $\begin{array}{l}\mathrm{n}^{0} \\
\text { abs. }\end{array}$ & $(\%)$ & $\begin{array}{l}\mathbf{n}^{0} \\
\text { abs. }\end{array}$ & $(\%)$ \\
\hline Vereador & 121 & 21,6 & 113 & 19,3 & 115 & 19,4 & 152 & 25,6 & 155 & 26,1 \\
\hline $\begin{array}{l}\text { Deputado Es- } \\
\text { tadual/Distrital }\end{array}$ & 203 & 36,3 & 225 & 38,5 & 208 & 35,0 & 203 & 34,2 & 203 & 34,2 \\
\hline Deputado Federal & 526 & 94,1 & 546 & 93,5 & 554 & 93,3 & 554 & 93,3 & 550 & 92,6 \\
\hline Senador & 78 & 13,9 & 91 & 15,6 & 90 & 15,2 & 88 & 14,8 & 90 & 15,2 \\
\hline Prefeito & 93 & 16,6 & 99 & 16,9 & 120 & 20,2 & 114 & 19,2 & 106 & 17,8 \\
\hline Governador & 26 & 4,6 & 35 & 6,0 & 38 & 6,4 & 39 & 6,6 & 38 & 6,4 \\
\hline Presidente & - & - & 1 & 0,2 & 1 & 0,2 & 1 & 0,2 & 1 & 0,2 \\
\hline
\end{tabular}

Fonte: Câmara dos Deputados (Repertório Biográfico) e Senado Federal (Dados Biográfi$\cos )$.

Obs: Os percentuais foram obtidos em relação ao total de parlamentares na respectivas legislaturas e não em relação ao total de respostas.

\section{Tabela 8C - Composição do Congresso Nacional, por número de mandatos e legislatura - Brasil - 1987 a 2004}

\begin{tabular}{|c|c|c|c|c|c|c|c|c|c|c|}
\hline \multirow{3}{*}{ Mandatos } & \multicolumn{10}{|c|}{ Legislatura } \\
\hline & \multicolumn{2}{|c|}{$87-91$} & \multicolumn{2}{|c|}{$91-95$} & \multicolumn{2}{|c|}{ 95-99 } & \multicolumn{2}{|c|}{ 99-03 } & \multicolumn{2}{|c|}{ 03-04 } \\
\hline & $\begin{array}{c}\mathbf{n}^{0} \\
\text { abs. }\end{array}$ & $\%$ & $\begin{array}{c}\mathbf{n}^{0} \\
\text { abs. }\end{array}$ & $\%$ & $\begin{array}{c}n^{0} \\
\text { abs. }\end{array}$ & $\%$ & $\begin{array}{c}\mathbf{n}^{0} \\
\text { abs. }\end{array}$ & $\%$ & $\begin{array}{c}\mathbf{n}^{0} \\
\text { abs. }\end{array}$ & $\%$ \\
\hline 1 & 328 & 58,7 & 352 & 60,3 & 153 & 25,8 & 147 & 24,7 & 243 & 40,9 \\
\hline 2 & 119 & 21,3 & 139 & 23,8 & 144 & 24,2 & 177 & 29,8 & 139 & 23,4 \\
\hline 3 & 61 & 10,9 & 48 & 8,2 & 161 & 27,1 & 146 & 24,6 & 115 & 19,4 \\
\hline 4 ou mais & 51 & 9,1 & 45 & 7,7 & 136 & 22,9 & 124 & 20,9 & 97 & 16,3 \\
\hline Total & 559 & 100 & 584 & 100 & 594 & 100 & 594 & 100 & 594 & 100 \\
\hline
\end{tabular}

Fonte: Câmara dos Deputados (Repertório Biográfico) e Senado Federal (Dados Biográfi$\cos )$. 


\section{Tabela 9C - Composição do Congresso Nacional, por rotatividade partidária ao longo da carreira Brasil - 1987 a 2004}

\begin{tabular}{l|cr|c|r}
\hline \multirow{2}{*}{$\mathbf{N}^{\mathbf{0}}$ de trocas de partido* } & \multicolumn{2}{|c|}{$\mathbf{8 7 - 9 5}$} & \multicolumn{2}{c}{$\mathbf{9 5 - 0 4}$} \\
\cline { 2 - 5 } & $\mathbf{n}^{\mathbf{0}}$ abs. & $\mathbf{( \% )}$ & $\mathbf{n}^{\mathbf{0}}$ abs. & \multicolumn{1}{c}{$\mathbf{( \% )}$} \\
\hline 0 & 306 & 29,6 & 324 & 29,0 \\
\hline & 383 & 37 & 306 & 27,4 \\
2 & 205 & 19,8 & 217 & 19,4 \\
\hline 3 & 93 & 9 & 132 & 11,8 \\
4 ou mais & 48 & 4,6 & 138 & 12,4 \\
Total & $\mathbf{1 0 3 5}$ & $\mathbf{1 0 0}$ & $\mathbf{1 1 1 7}$ & $\mathbf{1 0 0}$ \\
\hline
\end{tabular}

Fonte: Prodasen 